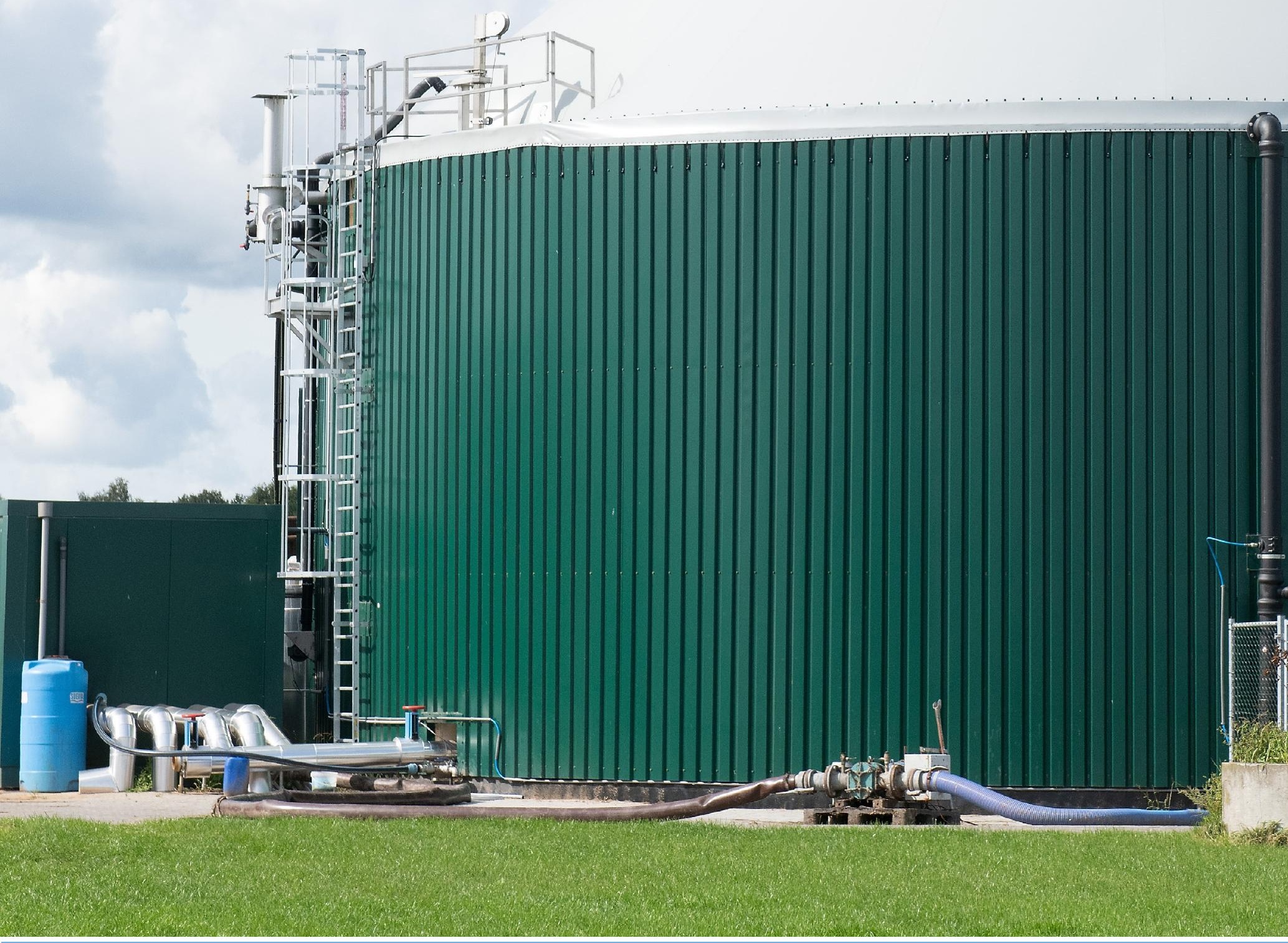

Effect mestvergisting op de emissies van broeikasgassen uit mest van melkvee

een literatuur- en scenariostudie

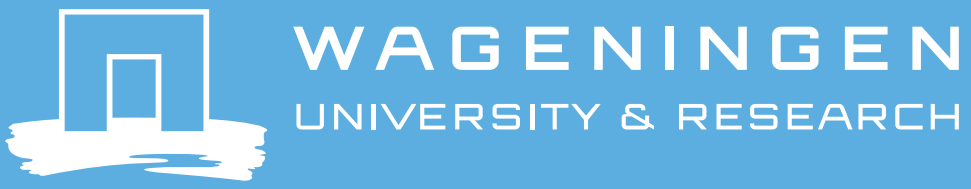





\section{Effect mestvergisting op de emissies van broeikasgassen uit mest van melkvee: een literatuur- en scenariostudie}

K. Groenestein, R.W. Melse, J. Mosquera, M. Timmerman

Dit onderzoek is uitgevoerd door Wageningen Livestock Research, in opdracht van en gefinancierd door het Ministerie van Landbouw Natuur en Voedselkwaliteit en FrieslandCampina 
Groenestein, K., R. Melse, J. Mosquera, M. Timmermans, 2020. Effect mestvergisting op de emissies van broeikasgassen uit mest van melkvee: een literatuur- en scenariostudie. Wageningen, WLR Rapport 1235.

\section{Samenvatting}

Het onderzoek in deze rapportage gaat in op het effect van mestvergisting op de carbon footprint van een melkveebedrijf middels een deskstudie en een rekenmodel met verschillende scenario's. Aan de hand van de uitkomsten worden enkele handelingsperspectieven voor de veehouder geschetst om de methaanemissies te reduceren. Deze studie is uitgevoerd in opdracht van het Ministerie van Landbouw, Natuur en Voedselkwaliteit en FrieslandCampina.

\section{Summary}

The research in this report examines the effect of manure digestion on the carbon footprint of a dairy farm by means of a desk study and a C flow model with different scenarios. Based on the results, a number of perspectives of action for the farmer are outlined to reduce methane emissions. This study was financed by the Ministry of Agriculture, Nature and Food quality and FrieslandCampina.

Dit rapport is gratis te downloaden op https://doi.org/10.18174/515098 of op www.wur.nl/livestock-research (onder Wageningen Livestock Research publicaties).

\section{(C) 2020 Wageningen Livestock Research}

Postbus 338, 6700 AH Wageningen, T 03174839 53, E info.livestockresearch@wur.nl, www.wur.nl/livestock-research. Wageningen Livestock Research is onderdeel van Wageningen University \& Research.

Wageningen Livestock Research aanvaardt geen aansprakelijkheid voor eventuele schade voortvloeiend uit het gebruik van de resultaten van dit onderzoek of de toepassing van de adviezen.

Alle rechten voorbehouden. Niets uit deze uitgave mag worden vermenigvuldigd en/of openbaar gemaakt worden door middel van druk, fotokopie, microfilm of op welke wijze dan ook zonder voorafgaande toestemming van de uitgever of auteur.

Wageningen Livestock Research is NEN-EN-ISO 9001:2015 gecertificeerd. Op al onze onderzoeksopdrachten zijn de Algemene Voorwaarden van de Animal Sciences Group van toepassing. Deze zijn gedeponeerd bij de Arrondissementsrechtbank Zwolle. 


\section{Inhoud}

$\begin{array}{lr}\text { Samenvatting } & 5\end{array}$

1

$\begin{array}{ll}\text { Inleiding } & 7\end{array}$

2

Broeikasgasemissies melkveehouderij: theoretische beschouwingen

2.1 Algemeen 18

2.2 Methaan uit mest $\quad 8$

2.3 Biochemisch Methaan Potentieel 9

2.4 Methaanconversiefactor $\quad 10$

2.5 Optimaliseren van het vergistingsproces 11

2.5.1 Milieuomstandigheden in de vergister $\quad 11$

2.5.2 Bedrijfsparameters 13

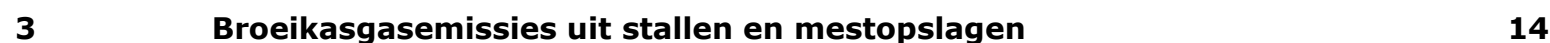

3.1 Methaan gemeten $\quad 14$

$\begin{array}{ll}3.2 \text { Methaan berekend } & 15\end{array}$

$\begin{array}{llr}4 & \text { Broeikasgasemissies door vergisten } & 18\end{array}$

$\begin{array}{llr}5 & \text { Koolstofbalans } & 21\end{array}$

$\begin{array}{llr}6 & \text { Scenariostudie mono-vergisting } & 25\end{array}$

5.1 Inleiding 25

5.2 Beschrijving uitgangspunten scenario's en model $\quad 25$

$\begin{array}{lll}5.3 & \text { Resultaten scenario-berekeningen } & 28\end{array}$

$\begin{array}{lll}5.4 & \text { Gevoeligheidsanalyse } & 30\end{array}$

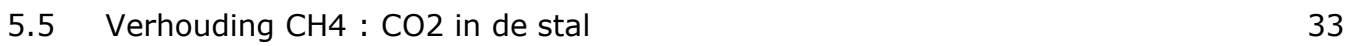

$\begin{array}{llr}7 & \text { Conclusie } & 36\end{array}$

$\begin{array}{ll}\text { Literatuur } & \mathbf{3 7}\end{array}$ 


\section{Samenvatting}

Het onderzoek in deze rapportage gaat in op het effect van mestvergisting op de carbon footprint van een Nederlands melkveebedrijf middels een deskstudie en een rekenmodel. Dat rekenmodel is een Cflow model waarmee diverse scenario's zijn doorgerekend om inzichten te krijgen in het effect van parameters en zo het handelingsperspectief in beeld te krijgen waarmee een veehouder de vergister optimaal kan laten functioneren.

Het rapport gaat allereerst in op de biochemische processen die ten grondslag liggen aan de emissie van methaan tijdens opslag van mest en vergisting. Vervolgens wordt ingegaan op resultaten van metingen en hoe nationale en internationale richtlijnen die nodig zijn om aan de verplichting te voldoen om de $\mathrm{CH}_{4}$-emissies te rapporteren in het kader van nationale, Europese en globale doelen om broeikasgassen te reduceren.

Belangrijke bronnen van methaan die in de internationale literatuur worden beschreven zijn de opslagen van mest en/of de scheidingsproducten, opslagen van digestaat en lekken uit de mestvergistingsinstallatie. Er is weinig melding van het effect van de opslag van mest in de stal omdat dat in de meeste landen in mindere mate wordt toegepast dan in Nederland.

In de scenariostudie is mono-vergisting op bedrijfsniveau vergeleken met de situatie waarin geen vergisting wordt toegepast. Aan de hand van de uitkomsten van de scenariostudie kon geconcludeerd worden dat de invloed van mate van weidegang op de CO2-footprint van het bedrijf beperkt is. Drie sleutelfactoren werden gedefinieerd: 1) duur van mestopslag in de stal, 2) duur van digestaatopslag met gasopvang en 3) lekkagepercentage van de vergistingsinstallatie. De eerste twee zijn de resultante van de dimensionering van de vergistingsinstallatie. Duidelijk wordt dat mest ten behoeve van een gunstige CO2-footprint snel vergist moet worden, in mindere mate omdat de energieopbrengst hoger is door het vergisten van verse mest, maar vooral door het vermijden van $\mathrm{CH} 4$-verliezen tijdens de opslag in de stal. Hoe langer de digestaatopslag met gasopvang is, hoe minder potentiele methaan nog over is om tijdens de tweede of derde digestaatopslag te emitteren. Ten derde, om lekkages van de installatie te voorkomen is het aan te bevelen de vergister periodiek te controleren en repareren. 


\section{$1 \quad$ Inleiding}

In het klimaatakkoord van Parijs is afgesproken dat de temperatuurstijging van de aarde minder zal zijn dan $1,5 \circ \mathrm{C}$. De Europese Unie heeft dat namens alle lidstaten vertaald in toezeggingen om de uitstoot van broeikasgassen in 2030 met minstens $40 \%$ te verminderen ten opzichte van 1990. Het kabinet Rutte III legt de lat nog hoger dan de toezegging die de EU gedaan heeft en heeft de ambitie om broeikasgasemissies te reduceren met $49 \%$ in 2030 , en $80 \%$ tot $95 \%$ in 2050 . FrieslandCampina heeft als bijdrage hiertoe ingezet op monovergisting van mest op melkveebedrijven die zijn aangesloten bij de coöperatie.

Het effect van mono-mestvergisting op de broeikasgasemissie van de zuivelketen is tweeledig; er wordt groene energie geproduceerd en de $\mathrm{CH}_{4}$ emissie uit de mestopslag neemt af doordat de mest zich minder lang of helemaal niet in de mestopslag bevindt. In welke mate de $\mathrm{CH}_{4}$ emissie uit de mestopslag of uit de stal afneemt is echter nooit in de praktijk vastgesteld. Ook de wetenschappelijke bewijsvoering voor lek uit mestvergisters en de emissie uit mestvergistingsproducten is beperkt, en in de Nederlandse context nagenoeg nihil.

Het verlagen van de carbon footprint van dierlijke producten wordt steeds belangrijker om de "licence to produce" voor de veehouderij in Nederland te kunnen behouden. Kennis over de broeikasgasemissies uit mest, wetenschappelijke onderbouwing en vertaling naar IPCC conforme rekenregels zijn noodzakelijk om maatregelen te kunnen implementeren die de carbon footprint van melk en vlees verlagen en om de emissiereducties te kunnen monitoren. Met de huidige IPCC rekenregels kunnen de effecten van mitigerende maatregelen echter niet geclaimd worden, behalve opslag korter en langer dan een maand. FrieslandCampina wenst op termijn de (voorkomen) emissies uit mestopslagen op bedrijven met mestvergisting op te nemen in het model waarmee bedrijfsspecifiek de carbon footprint wordt berekend. IPCC schrijft voor dat specifieke berekeningen alleen kunnen worden toegepast als deze voldoende wetenschappelijk onderbouwd zijn. Deze wens en de eis van de IPCC vormen de basis van onderhavig onderzoek.

Middels een deskstudie zal een inventarisatie gemaakt worden van de internationale kennis omtrent methaanemissie uit stallen en opslagen, alsmede van de processen en factoren die hierbij een rol spelen, mede gedurende vergisting.

Activiteiten:

- Deskstudie: Kennis over broeikasgasemissies en $C$ balans van internationale literatuur wordt in beeld gebracht en broeikasgasemissies en $C$ balans van melkveebedrijven zonder mestvergisting en verschillende bestaande mestvergistingsconcepten /-scenario's worden doorgerekend op basis van de huidige kennis.

- $\quad$ Potentiele mitigatiemaatregelen om de broeikasgasemissies van melkveestallen met vergisting te reduceren binnen het handelingsperspectief van de boer worden besproken en doorgerekend met het C-balansmodel. 


\section{Broeikasgasemissies melkveehouderij: theoretische beschouwingen}

\section{$2.1 \quad$ Algemeen}

Broeikasgassen in de melkveehouderij betreffen $\mathrm{CH}_{4}$ productie in de pens (endogene $\mathrm{CH}_{4}$-productie), $\mathrm{CH}_{4}$ en $\mathrm{N}_{2} \mathrm{O}$ uit mest en $\mathrm{CO}_{2}$ door het gebruik van fossiele brandstoffen. Deze studie betreft het effect van mestvergisting op de $\mathrm{CO}_{2}$ footprint van rauwe melk en laat daarom de endogene $\mathrm{CH}_{4}$ buiten beschouwing omdat die niet wijzigt door vergisting. De meeste $\mathrm{N}_{2} \mathrm{O}$ uit de landbouw ontstaat na toediening van mest op het land en in vaste mest. Omdat het in de reguliere melkveehouderij vooral drijfmestopslag betreft onder anaerobe omstandigheden wordt de bijdrage en de verandering van $\mathrm{N}_{2} \mathrm{O}$ door vergisten, hier verwaarloosbaar geacht. Deze studie betreft dus de verandering van de $\mathrm{CH}_{4}$ emissies uit mest en de reductie van $\mathrm{CO}_{2}$ uit fossiele brandstof door het gebruik van $\mathrm{CH}_{4}$ uit mest als energiedrager.

\section{$2.2 \quad$ Methaan uit mest}

Methaan $\left(\mathrm{CH}_{4}\right)$ ontstaat door afbraak van organische stof (OS) in de mest. De hoeveelheid en samenstelling van de OS hangt af van de kwaliteit en de kwantiteit van het voer, huisvesting en mestmanagement. Behalve de mest die onder de staart het dier verlaat kunnen ook strooisel en voerresten in de mest terecht komen. Over het algemeen wordt weinig strooisel gebruikt in reguliere melkveestallen. Daar komt bij dat het veelal zaagsel betreft dat veel lignine bevat en daarmee slecht afbreekbaar is. De hoeveelheid $\mathrm{CH}_{4}$ die hierdoor gevormd wordt, wordt verwaarloosd. Wel wordt er rekening mee gehouden dat een deel van het voer in de mestput terecht komt. Volgens Vonk et al. (2018) bedraagt dit 3\% van het voer. Bij de afbraak van OS ontstaat behalve $\mathrm{CH}_{4}$, ook $\mathrm{CO}_{2}$. Dit draagt niet bij aan het versterkte broeikaseffect, want is onderdeel van de korte koolstofcyclus (Groth et al. 2015). Deze $\mathrm{CO}_{2}$ wordt weer opgenomen door de plant en via fotosynthese opgeslagen totdat de plant weer wordt opgegeten door de koe. Deze cyclus voegt dus geen extra $\mathrm{CO}_{2}$ toe aan de atmosfeer.

In de IPCC Guidelines wordt voorgesteld de excretie van OS te schatten op basis van de energie-inhoud van het voer, en gebruiken daarvoor de Digestibel en Bruto (Gros) energiegehalten van het voer (respectievelijk DE en GE) (IPCC 2006). Voor Nederland is dat niet praktisch omdat Nederland deze grootheden niet gebruikt. In Nederland wordt de energie-inhoud uitgedrukt in VEM (Voeder-EenheidMelk). Vóór 2015 schatte Nederland de excretie van de OS daarom op basis van de mestanalyses die werden gedaan ten behoeve van de bemestingsadviezen (Boer et al. 2012). Deze waarden werden echter bepaald na de opslag, vóór toedienen van de mest. Een deel van de OS was derhalve al vervluchtigd als $\mathrm{CO}_{2}$ en $\mathrm{CH}_{4}$ en $\mathrm{H}_{2} \mathrm{O}$. Zom en Groenestein (2015) stelden daarom voor om de OS excretie rechtstreeks af te leiden uit de verteerbaarheid van de organische stof. Dit mondde uit in een OS excretie van melkvee die 3\% hoger was dan voorheen in de NIR, en 3\% lager dan zou zijn berekend met de IPCC methode, gebruik makend van de hoogste DE, wat redelijk is voor de Nederlandse voergift (Groenestein et al. 2015).

De IPCC Guidelines stellen dat het deel van de OS dat uiteindelijk wordt omgezet in $\mathrm{CH}_{4}$ afhangt van het maximum dat biochemisch is om te zetten in $\mathrm{CH}_{4}$, gedefinieerd als Biochemisch Methaan Potentieel (BMP) en het deel dat daadwerkelijk wordt omgezet afhankelijk van de omstandigheden: de Methaan Conversie Factor (MCF). Deze factoren worden nader beschouwd in onderstaande paragrafen. 
Naast de BMP en de MCF wordt in dit rapport ook gesproken over de specifieke methaanemissie $\left(\varepsilon \mathrm{CH}_{4}\right)$ die de $\mathrm{CH}_{4}$-emissie uitdrukt in $\mathrm{kg} \mathrm{CH}$ per $\mathrm{kg}$ OS, berekend als BMP $\times$ MCF $\mathrm{x}$ dichtheid van $\mathrm{CH}_{4}(0,67$ $\mathrm{kg} / \mathrm{m3})$.

Studies met mest hebben al aangetoond dat opslagtermijn een belangrijke factor is voor $\mathrm{CH}_{4}$-emissie. Het legen van mestputten in de stal kan het ontstaan van methanogenese uitstellen (Haesserman et al., 2006; Groenestein et al., 2016). Baldé et al., 2016 concluderen dat onder Canadese weersomstandigheden het legen van de silo een aantoonbaar reducerend effect heeft op de jaarlijkse $\mathrm{CH}_{4}$-emissies van silo's (20\%) als dat gebeurt in de late zomer en vroege herfst. Zij toonden bovendien aan dat ca $90 \%$ van de jaarlijkse emissie plaatsvindt tussen juli en september, waarvan het merendeel in augustus. De winters in Canada zijn over het algemeen heel koud, en de zomers warmer dan bij ons, waardoor het effect versterkt wordt, maar het geeft wel aan dat er gedegen rekening moet worden gehouden met de afhankelijkheid van de factoren opslagtermijn en temperatuur. Voor de Nederlandse en Europese situatie kan legen van silo's in de herfst niet vanwege het uitrijverbod en opslag in de wintermaanden dus toeneemt, in de zomer wordt de mest uitgereden en is er dus minder in opslag.

\subsection{Biochemisch Methaan Potentieel}

De IPCC gaat uit van de $\mathrm{CH}_{4}$-emissie uit opslag, en onderscheid daarmee niet wat voor opslag het is. Dientengevolge berekenen lidstaten de emissie integraal, zonder onderscheid te maken tussen opslag in de stal, opslag buiten de stal of voor gescheiden fracties. De BMP van een mestsoort wordt in een laboratoriumopstelling bepaald. Onder voor $\mathrm{CH}_{4}$-vorming ideale omstandigheden wordt in een afgesloten container gemeten hoeveel $\mathrm{CH}_{4}$ geproduceerd wordt gedurende 60-90 dagen (Angeledeki, 2009).

In de praktijk varieert de BMP door verandering van de voersamenstelling en de verteerbaarheid van het voer. Dämmgen et al. (2012) vonden in de literatuur meetwaarden voor de BMP voor melkvee van 0,10$0,24 \mathrm{~m}^{3} \mathrm{CH} 4 / \mathrm{kg}$ OS. Baral et al. (2018) werkten met een model op basis van de Arrheniusvergelijking die eerder was uitgewerkt door Sommer et al. (2004). Zij concludeerden dat de BMP verandert gedurende de opslagperiode en niet voorspeld kan worden met alleen OS en T als variabelen (zie Kader 1). Daar komt bij dat Petersen et al. (2016) vonden dat in de stal meer $\mathrm{CO}_{2}$ dan $\mathrm{CH}_{4}$ vervluchtigt, terwijl in het laboratorium en in de vergister die verhouding 40:60 is. Hij pleit ervoor de BMP in het laboratorium met een luchtflow over het emitterend oppervlak te bepalen (Pedersen, persoonlijke communicatie). 
Kader 1. De Arrheniusvergelijking

De Arrheniusvergelijking is een universele vergelijking die de reactiesnelheid voorspelt, bij een bepaalde temperatuur, gezien de activeringsenergie en de kans van succesvolle botsing van moleculen.

$$
F_{C H 4}=\left(V S_{d}+0.01 V S_{n d}\right) e^{\left[\ln (A)-\frac{E_{a}}{R T}\right]} \times 24
$$

Met:

$\mathrm{F}_{\mathrm{CH} 4}=$ emissiesnelheid in $\mathrm{g} \mathrm{CH}_{4}$ per $\mathrm{kg}$ OS per dag

$\mathrm{VS}_{d}=$ makkelijk afbreekbare organische stof

$\mathrm{VS}_{\text {nd }}=$ niet makkelijk afbreekbare organische stof

$\mathrm{A}=$ de pre-exponentiele factor in $\mathrm{g} \mathrm{CH}_{4} \mathrm{~kg} \mathrm{OS}^{-1} \mathrm{uur}^{-1}$

$\mathrm{E}_{a}=$ activeringsenergie in $\mathrm{J} / \mathrm{mol}$

$\mathrm{R}=$ gasconstante, $8,3 \mathrm{~J} \mathrm{~mol}^{-1} \mathrm{~K}^{-1}$

$\mathrm{T}=$ Temperatuur

De factoren A en Ea zijn specifiek voor een reactie en onafhankelijk van temperatuur. Petersen et al.

(2016) heeft aan de hand van proeven bepaald dat de Ea van runderdrijfmest $81 \mathrm{kj} / \mathrm{mol}$ is en dat $\ln (\mathrm{A})$

$31,2 \mathrm{~g} \mathrm{CH}_{4} \mathrm{~kg} \mathrm{OS}^{-1}$ uur $^{-1}$ is.

Bron: Sommer et al., 2004

\subsection{Methaanconversiefactor}

De MCF is afhankelijk van externe omgevingsfactoren. De belangrijkste zijn: temperatuur, verblijftijd van de mest in opslag/vergister (retentietijd) en enting met methaanvormende bacteriën (inoculum) (VanderZaag et al. 2018). De afhankelijkheid van deze factoren geeft aan dat mestmanagement bepalend is voor het deel van de potentiele $\mathrm{CH}_{4}$-productie die tot uitdrukking komt. Anaerobe mestmeren (komen in Nederland niet voor, maar wel bv in de US) laten een MCF zien van 50-80\%, droge vaste mest 2-5\%. Hogere temperaturen en langere retentietijden gaan gepaard met hogere MCF (Liu and Liu 2018). Jayasundara et al. (2016) vonden voor rundveemest in Canada een MCF van 0,25 gedurende het warme seizoen, en 0,04 voor het koude seizoen. Wanneer mest elke paar uur of elke dag uit de stal wordt verwijderd, krijgen methanogene bacterieen niet de kans om te ontwikkelen en $\mathrm{CH}_{4}$ te vormen. Met diepe putten onder de roosters wordt de mest anaeroob en langdurig opgeslagen en de methanogenese kan goed op gang komen. Dat wordt versterkt wanneer bij het leeghalen van de put niet alle mest verwijderd wordt en een rest als inoculum achterblijft. Om welzijnsredenen worden strooiselsystemen populairder. Deze systemen slaan de mest langdurig op terwijl stro wordt toegevoegd. De dieren lopen en mesten op het mengsel van stro en mest. Omdat de dieren het mengsel van stro en mest aanstampen, wordt het anaeroob. Het stro dient bovendien als energiebron voor de methanogene bacteriën. Groenestein en Reitsma (1993) hebben de $\mathrm{CH}_{4}$-emissie van zo'n potstal gemeten. De $\mathrm{CH}_{4}$-emissies bedroegen zo'n $200 \mathrm{~g}$ per kg OS (Monteny et al., 2001; Zom en Groenestein, 2015). Dat is een factor 8 hoger dan de emissie van drijfmest van melkvee met $25 \mathrm{~g} / \mathrm{kg}$ OS (Groenestein et al., 2016 ). 


\subsection{Optimaliseren van het vergistingsproces}

Het doel van een mestvergistingsinstallatie is om biogas te produceren wat vervolgens omgezet kan in een WKK-installatie in elektriciteit en warmte of in een opwaarderingsinstallatie waar het biogas wordt opgewerkt tot aardgaskwaliteit.

Het biogas ontstaat in een biologisch anaeroob proces waarbij micro-organismen organisch materiaal omzetten tot een gasmengsel (het biogas). Het biogas bestaat voor het overgrote deel uit $\mathrm{CH}_{4}(50-75 \%)$ en koolstofdioxide $\left(\mathrm{CO}_{2}\right)(25-50 \%)$ met daarnaast met (zeer) kleine hoeveelheden andere gassen zoals waterstof, zwavelwaterstofgas, lachgas en ammoniak. Daarnaast bevindt zich waterdamp in het biogas. De samenstelling van het biogas wordt sterk bepaald door het ingaande organisch materiaal en het verloop van het vergistingsproces. Het vergistingsproces kan worden onderverdeeld in vier fasen waarin specifieke groepen micro-organismen een rol spelen:

- Hydrolyse: in deze eerste fase worden complexe, onopgeloste organische stoffen omgezet naar eenvoudige, opgeloste organische stoffen

- Verzuring (acidogenesis): omzetting van eenvoudige, opgeloste organische stoffen naar vluchtige vetzuren en $\mathrm{CO}_{2}$

- $\quad$ Azijnzuurvorming (acetogenesis): omzetting van vluchtige vetzuren naar azijnzuur en waterstof

- Methaanvorming (methagonese): omzetting van azijnzuur en koolstofdioxide en waterstof in methaan.

Bij mestvergistingsinstallaties vindt het vergistingsproces meestal plaats in één geroerde tank waarin alle processen tegelijkertijd plaatsvinden. In Figuur 1 staat schematisch het vergistingsproces weergegeven.

\subsubsection{Milieuomstandigheden in de vergister}

\section{Temperatuur}

De micro-organismen die het vergistingsproces mogelijk maken kunnen op basis van hun optimale omgevingstemperatuur in drie groepen worden ingedeeld (FNR, 2010):

1. Psychrofiele micro-organismen hebben hun optimale temperatuur beneden de $25^{\circ} \mathrm{C}$. Bij deze temperatuur is verwarming van de vergister meestal niet nodig. Echter de verblijftijden zijn hierdoor langer en de biogasopbrengsten lager.

2. Mesofiele micro-organismen hebben hun optimale temperatuur tussen de 37 en $42^{\circ} \mathrm{C}$. In de praktijk worden de meeste mestvergisters in dit temperatuurbereik bedreven vanwege de relatieve hoge biogasopbrengsten en goede processtabiliteit.

3. Thermofiele micro-organismen hebben hun optimale temperatuur tussen de 50 en $60^{\circ} \mathrm{C}$. Bij een hogere temperatuur wordt een hogere afbraaksnelheid bereikt en kan met kortere verblijftijden worden gewerkt, maar het vergistingsproces is bij deze temperaturen ook gevoeliger voor verstoringen en een onregelmatige toevoer van organisch materiaal.

Voor een stabiel procesverloop is het belangrijker om een vrij constante temperatuur te handhaven, wat in de praktijk gebeurt d.m.v. verwarming van de vergister via temperatuurregeling waarmee op de vergister op een ingestelde temperatuur wordt gehouden. Voor de verwarming wordt in het algemeen een deel van de warmte van de WKK-installatie ingezet. 


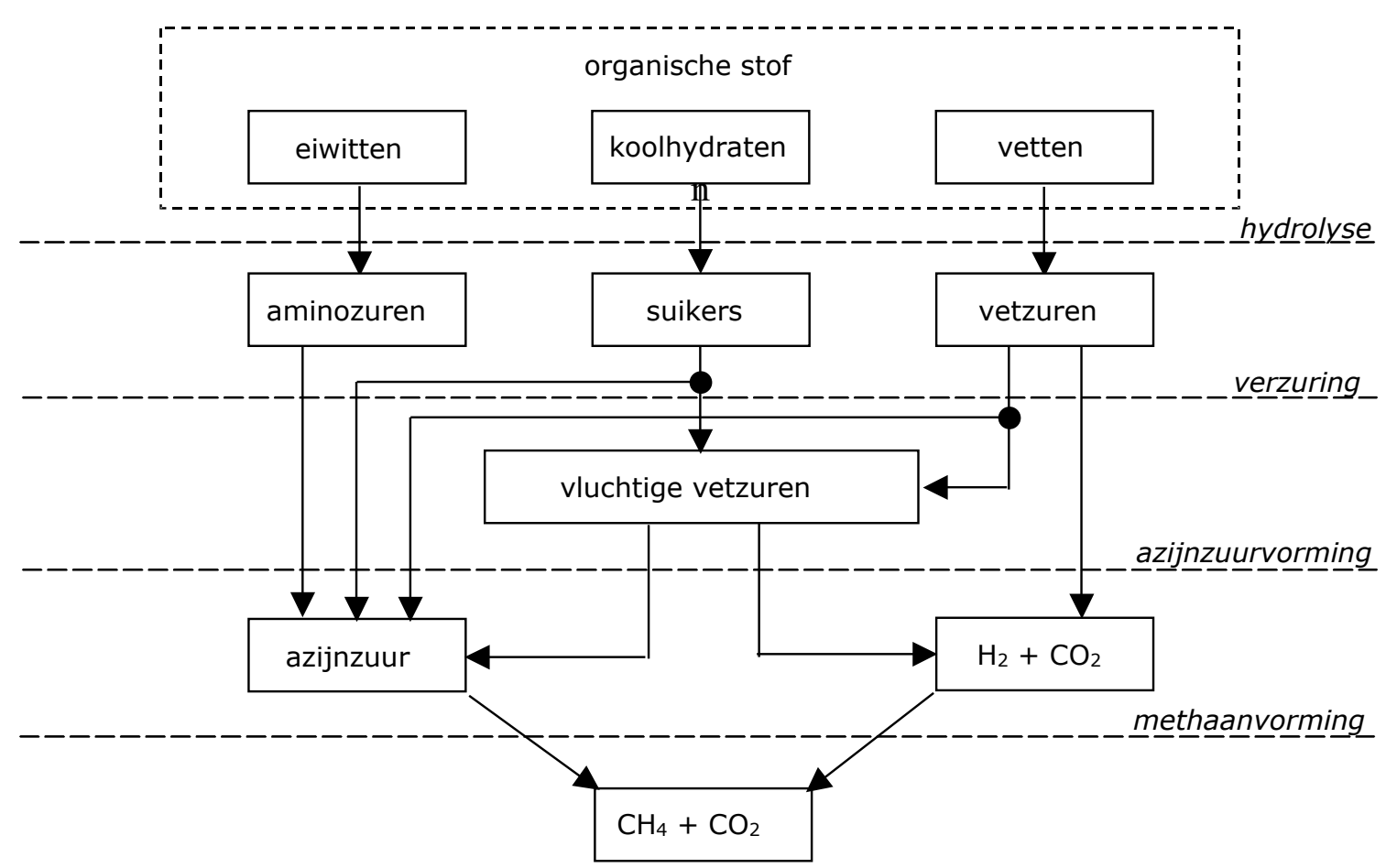

Figuur 1 Vereenvoudigde schematische weergave van het vergistingsproces (Sanders 2001).

\section{Zuurgraad $(\mathrm{pH})$}

De verschillende micro-organismen in het vergistingsproces hebben hun eigen optimale zuurgraad $(\mathrm{pH})$. Voor de hydrolyserende en zuurvormende bacteriën ligt het optimum tussen een $\mathrm{pH}$ van 5,2 en 6,3, maar ook bij hogere $\mathrm{pH}$ zijn deze bacteriën nog actief. Voor de azijnzuurvormende en $\mathrm{CH}_{4}$-vormende bacteriën ligt het optimum tussen een $\mathrm{pH}$ van 6,5 en 8,0 . Vinden alle processen plaats in één vergistingstank, dan ligt de $\mathrm{pH}$ van het vergistingsproces meestal tussen de 7 en 8 . De pH wordt bepaald door de basen en zuren die aanwezig zijn in het organisch materiaal (zoals mest) en die ontstaan tijdens het vergistingsproces. Mest heeft een $\mathrm{pH}$ van circa 7,0 à 7,5 en een hoog gehalte aan carbonaat en ammonium waardoor het beschikt over een groot carbonaat- en ammoniakbufferevenwicht.

Schommelingen in de hoeveel zuren en basen in de vergister worden goed opgevangen en gebufferd waardoor de $\mathrm{pH}$ in een mestvergister over het algemeen erg stabiel is.

Remmende stoffen en verontreinigingen

Er kunnen stoffen voorkomen die een remmende werking hebben op het vergistingsproces waardoor een lagere biogasproductie wordt gerealiseerd. Dit kunnen enerzijds stoffen zijn die ontstaan tijdens het vergistingsproces en anderzijds stoffen die met het organisch materiaal de vergister worden ingebracht. Absolute grenzen voor te hoge concentraties zijn moeilijk aan te geven vanwege het grote adaptatie vermogen van micro-organismen. Voor niet aan hoge stikstofgehalten aangepaste micro-organismen heeft ammoniak een remmende werking bij $80-250 \mathrm{mg} / \mathrm{l}$. Afhankelijk van temperatuur en $\mathrm{pH}$ komt dit overeen met een ammoniumgehalte van 1,7-4,0 g/l. Praktijkervaringen duiden op een ammoniumgehalte van 3,0-3,5 g/l waar vanaf remmingen beginnen op te treden. Tijdens het vergistingsproces wordt ook zwavelwaterstof gevormd, wat in opgeloste vorm al in concentraties vanaf $50 \mathrm{mg} / \mathrm{l}$ remmend kan werken op het proces. Antibiotica, schoonmaak- en reinigingsmiddelen kunnen vanaf geringe hoeveelheden ook een remmende werking op het proces hebben (FNR, 2010). 


\subsubsection{Bedrijfsparameters}

\section{Verblijftijd}

De verblijftijd geeft aan wat de gemiddeld tijdsduur is van invoer van de mest tot aan afvoer uit de vergister. De verblijftijd wordt berekend door de netto inhoud van de vergistingstank te delen door de gemiddeld dagelijkse toegevoerde hoeveelheid. Bij een te korte verblijftijd hebben de bacteriën te weinig tijd om de toegevoerde organische stof af te breken en om te zetten in biogas en is de afvoer van bacteriën groter dan de aanwas. Daarom dient de verblijftijd zo gekozen worden dat deze past bij de afbraaksnelheid van de toegevoerde producten. Over het algemeen ligt de verblijftijd bij mestvergistingsinstallaties tussen de 20 en 45 dagen.

Organische stofbelasting

De organische stofbelasting geeft aan wat de biologische belasting van het vergistingsproces is. Hiermee wordt aangegeven hoeveel kilogram organische stof (os) per kubieke meter inhoud van de vergistingstank per dag toegevoerd wordt. Een grove vuistregel voor de bovengrens van de organische stofbelasting is 4 à $5 \mathrm{~kg} \mathrm{os} / \mathrm{m}^{3}$ per dag. Bij hogere belastingen wordt de organische stof slechter omgezet wat leidt tot een lagere biogasproductie per kilogram stof en remming van het vergistingsproces. De organische stofbelasting is gekoppeld aan de verblijftijd. Hoe hoger de input naar een bepaalde vergister, hoe korter de verblijfstijd en hoe hoger de organische stofbelasting. 


\section{Broeikasgasemissies uit stallen en mestopslagen}

\subsection{Methaan gemeten}

In dit hoofdstuk wordt een overzicht gegeven van het aantal metingen die in melkveestallen uitgevoerd zijn om onder andere $\mathrm{CH}_{4}$-emissies te bepalen. Deze metingen zijn uitgevoerd volgens de meetprotocollen beschreven in [10] (Groenestein e.a., 2011) voor $\mathrm{CH}_{4}$. De metingen zijn op stalniveau uitgevoerd, met als gevolg dat per stal geen onderscheid kan worden gemaakt tussen de emissies uit het dier (enterische $\mathrm{CH}_{4}$ ) en uit de mest. Om toch een beeld te krijgen van de hoogte van deze twee verschillende emissiebronnen, is de beschikbare data geanalyseerd op basis van vloeruitvoering: aan de ene kant stallen met dichte vloer, aan de andere kant stallen met roostervloer. De emissie van de mest op de vloer is verwaarloosbaar omdat de mest vaak verwijderd wordt en omdat de omstandigheden op de vloer aeroob zijn. Of de veronderstelling dat met dichte vloeren alleen enterische $\mathrm{CH}_{4}$ wordt gemeten juist is, wordt op het moment dat dit rapport wordt opgesteld proefondervindelijk vastgesteld (Ogink, persoonlijke communicatie). Een kelder is namelijk niet helemaal gasdicht, dan zouden gevaarlijke mestgassen zich op kunnen hopen. De vraag is hoe dicht een kelder moet zijn om $\mathrm{CH}_{4}$ emissie uit mest in de stal te voorkomen.

In Tabel 1 wordt een samenvatting van de beschikbare data en de berekende emissies weergegeven. De metingen zijn verricht volgens protocol (Groenestein et al., 2011; Mosquera et al., 2011). Gemiddelde over alle metingen met een dichte vloer $(n=7)$ wordt een veronderstelde enterische $\mathrm{CH}_{4}$-emissie van 88 $\mathrm{kg} \mathrm{CH} /$ jaar per dierplaats berekend. Ten opzichte van de Tier 3 berekening van zo'n $125 \mathrm{~kg} \mathrm{CH}_{4}$ per dier per jaar ten behoeve van de Nationale Inventory Report (NIR) is dit een lage schatting (van Bruggen et al., 2018). De bijdrage uit de mest is, als het verschil van de gemiddelden tussen een roostervloer (129) en een dichte vloer (88), $41 \mathrm{~kg} \mathrm{CH} /$ jaar per dierplaats bij een volledige bezetting van de stal (leegstand wordt voor melkvee niet gerekend).

Tabel 1 Overzicht van protocolair gemeten data en gemeten $\mathrm{CH}_{4}$-emissies (DVLn is Dichte vloer Locatie n; RVLn is Roostervloer Locatie $n$.

\begin{tabular}{|c|c|c|c|c|}
\hline Vloeruitvoering & Locatie & Aantal meetdagen & $\begin{array}{c}\mathrm{CH}_{4} \\
{[\mathrm{~kg} / \mathrm{jaar} \text { per dierplaats] }}\end{array}$ & Referentie \\
\hline Dicht & DVL1 & 6 & 71 & [1] \\
\hline Dicht & DVL2 & 6 & 118 & {$[2]$} \\
\hline Dicht & DVL3 & 5 & 71 & [3] \\
\hline Dicht & DVL4 & 6 & 92 & [4] \\
\hline Dicht & DVL5 & 6 & 88 & [5] \\
\hline Dicht & DVL6 & 6 & 87 & {$[6]$} \\
\hline Dicht & DVL7 & 6 & 85 & [7] \\
\hline Totaal (dicht) & 7 & 41 & -- & \\
\hline Gemiddelde (dicht) & -- & -- & $88 \pm 16$ & \\
\hline Roostervloer & RVL1 & 4 & 127 & [8] \\
\hline Roostervloer & RVL2 & 5 & 106 & {$[8]$} \\
\hline Roostervloer & RVL3 & 5 & 189 & {$[8]$} \\
\hline Roostervloer & RVL4 & 5 & 123 & [8] \\
\hline Roostervloer & RVL5 & 6 & 101 & [9] \\
\hline
\end{tabular}




\section{Literatuur bij Tabel 1:}

[1] Mosquera, J., J.M.G. Hol, J.W.H. Huis in 't Veld, J.P.M. Ploegaert en N.W.M. Ogink (2012). Emissies uit een ligboxenstal voor melkvee met het "vrije keuze" systeem. Meetprogramma Integraal Duurzame Stallen. Wageningen UR Livestock Research Rapport 617

[2] Mosquera, J., J.M.G. Hol, J.W.H. Huis in 't Veld, J.P.M. Ploegaert en N.W.M. Ogink (2012). Emissies uit een ligboxenstal voor melkvee met het "vrije keuze" systeem. Meetprogramma Integraal Duurzame Stallen. Wageningen UR Livestock Research Rapport 614.

[3] Mosquera, J., J.M.G. Hol, J.W.H. Huis in 't Veld, J.P.M. Ploegaert en N.W.M. Ogink (2012). Emissies uit een ligboxenstal voor melkvee met het "vrije keuze" systeem. Meetprogramma Integraal Duurzame Stallen. Wageningen UR Livestock Research Rapport 615.

[4] Mosquera, J., J.M.G. Hol, J.W.H. Huis in 't Veld, J.P.M. Ploegaert en N.W.M. Ogink (2012). Emissies uit een ligboxenstal voor melkvee met het "vrije keuze" systeem. Meetprogramma Integraal Duurzame Stallen. Wageningen UR Livestock Research Rapport 616.

[5] Mosquera, J., J.M.G. Hol, J.W.H. Huis in 't Veld, J.P.M. Ploegaert en N.W.M. Ogink (2012). Emissies uit een ligboxenstal voor melkvee met roostervloer voorzien van een bolle rubber toplaag en afdichtflappen in de roosterspleten. Meetprogramma Integraal Duurzame Stallen. Wageningen UR Livestock Research Rapport 610.

[6] Mosquera, J., J.M.G. Hol, J.W.H. Huis in 't Veld, J.P.M. Ploegaert en N.W.M. Ogink (2012). Emissies uit een ligboxenstal voor melkvee met roostervloer voorzien van een bolle rubber toplaag en afdichtflappen in de roosterspleten. Meetprogramma Integraal Duurzame Stallen. Wageningen UR Livestock Research Rapport 612.

[7] Mosquera, J., J.M.G. Hol, J.W.H. Huis in 't Veld, J.P.M. Ploegaert en N.W.M. Ogink (2012). Emissies uit een ligboxenstal voor melkvee met roostervloer voorzien van cassettes in de roosterspleten. Meetprogramma Integraal Duurzame Stallen. Wageningen UR Livestock Research Rapport 653.

[8] Mosquera, J., J.M.G. Hol, A. Winkel, J.W.H. Huis in 't Veld, F.A. Gerrits, N.W.M. Ogink, A.J.A. Aarnink (2011). Fijnstofemissie uit stallen: melkvee. Wageningen UR Livestock Research Rapport 296 (herziene versie).

[9] Mosquera, J., J.M.G. Hol, J.W.H. Huis in 't Veld, J.P.M. Ploegaert en N.W.M. Ogink (2012). Emissies uit een ligboxenstal voor melkvee met roostervloer voorzien van een bolle rubber toplaag. Meetprogramma Integraal Duurzame Stallen. Wageningen UR Livestock Research Rapport 598.

\subsection{Methaan berekend}

Nederland rapporteert nationaal en internationaal de emissies van broeikasgassen uit onder meer landbouw in het kader van diverse protocollen en regelingen (o.a. Kyoto protocol, E-PRTR (European Pollutant Release and Transfer Register)). Emissieregistratie (ER) is verantwoordelijk voor de jaarlijkse vaststelling van deze emissiegegevens en rapporteert deze in de NIR. Met het National Emission Model for Agriculture (Lagerwerf et al., 2019) worden de emissies naar lucht uit de landbouw berekend, waaronder de $\mathrm{CH}_{4}$-emissie uit mest. In hoofdstuk 2 van dit rapport is al beschreven dat onderzoeken aantonen dat deze methode beter zou moeten kunnen, maar meer onderzoek is nodig om dit te verwezenlijken. Eén belangrijk nadeel van deze rekenmethode is dat maatregelen die $\mathrm{CH}_{4}$-emissies reduceren met deze methode niet tot uitdrukking kunnen komen. Een ander nadeel van deze methodiek die daaraan gekoppeld is dat geen onderscheid gemaakt wordt tussen verschillende opslagmethoden: in 
de stal en daarbuiten. Maatregelen die je in de stal neemt, moet je kunnen onderscheiden van maatregelen die je in de buitenopslag neemt om de emissie te reduceren.

Vooralsnog blijft de IPCC methodiek gehandhaafd om de nationale emissies van $\mathrm{CH}_{4}$ door de veehouderij te berekenen. Voor de belangrijkste diercategorieën rundvee, varkens en pluimvee wordt de Tier 2 procedure gevolgd zoals die is beschreven door Safley et al. (1992) en zoals eerder genoemd in onderhavig rapport: de emissiefactor per kg mest is het product van de hoeveelheid OS in de mest, de fractie van de OS die afbreekbaar is (Biochemisch Methaan Potentieel; Bo of BMP) en het deel van de afbreekbare fractie die daadwerkelijk wordt afgebroken tot $\mathrm{CH}_{4}$ (methaanconversiefactor; MCF). De vergelijking wordt dan:

$$
\mathrm{CH}_{4}=\mathrm{OS} * \mathrm{BMP} * \mathrm{MCF}
$$

Zom en Groenestein (2015) beschrijven de methode die Nederland hanteert om de excretie van OS te berekenen op basis van voergegevens en verteringscoëfficiënten (zie ook paragraaf 2.2). Het voordeel van deze methode is dat dit de OS productie 'onder de staart' berekent voordat organische stof is afgebroken en de daaruit voortvloeiende emissies van vluchtige organische componenten hebben plaatsgevonden. Een tweede voordeel is dat het met deze methodiek niet nodig is om in de berekening mestvolumes per dier per jaar mee te nemen. Schattingen van mestvolumes zijn over het algemeen onnauwkeurig.

De excreties die op deze manier berekend zijn voor rundvee zijn in Tabel 2 weergegeven. Dit is gebaseerd op voergegevens en productiecijfers van 1995 en 2013. De duidelijke toename van de excretie van OS door melkkoeien wordt enerzijds veroorzaakt door een hogere voergift vanwege een hogere melkproductie. Maar anderzijds door een veranderend rantsoen: er wordt een groter aandeel snijmais gevoerd. Ten derde is door het mestbeleid minder $\mathrm{N}$ op het land gebracht, wat leidt tot een lagere verteerbaarheid van gras en graskuil. Zowel meer voeropname, meer mais, als een lagere verteerbaarheid van het gras leiden tot een hogere OS-excretie.

Tabel 2 Excretie van organische stof door melkvee en jongvee in 1995 en 2013 op basis van opname van organische stof en verteerbaarheid van de voercomponenten, $\mathrm{kg} / \mathrm{j}$ per dier.

\begin{tabular}{lcc} 
& 1995 & 2013 \\
Melkvee & 1436 & 1712 \\
\hline Jongvee $<1$ jaar & 393 & 394 \\
\hline Jongvee $>1$ jaar & 746 & 782 \\
\hline
\end{tabular}

Groenestein et al. (2016) hebben een schatting gemaakt van de BMP en de MCF voor rundveemest. De BMP werd geschat op basis van waarden uit 42 studies. Voor de MCF konden niet veel studies gevonden worden die pasten bij de Nederlandse situatie en werd uitgegaan van de review van Dämmgen et al., 2012. De uitkomsten worden in Tabel 3 weergegeven. De specifieke $\mathrm{CH}_{4}$-emissie $(\mathrm{kg} \mathrm{CH}$ per $\mathrm{kg} \mathrm{OS})$ is eveneens uitgerekend. Het NIR rapport daarvoor rapporteerde voor BMP 0,25 en eveneens 0,17 voor de MCF (Coenen, van der Maas et al. 2016). Dämmgen et al. (2012) geven ook nog een MCF van 0.11 voor opgeslagen runderdrijfmest met een korst. Gezien de Nederlandse situatie met weinig strooisel in de boxen, gaan wij hier niet vanuit, maar het is wel een aspect om in het achterhoofd te houden.

Tabel 3 Potentiele $\mathrm{CH}_{4}$-emissie uit mest (BMP), $\mathrm{CH}_{4}$-conversiefactor (MCF) voor rundveemest en de specifieke methaanemissie $\left(\mathrm{ECH}_{4}\right)$.

\begin{tabular}{llll} 
& $\mathrm{BMP}\left(\mathrm{m}_{3} \mathrm{CH}_{4} / \mathrm{kg} \mathrm{OS}\right)$ & MCF & $\mathcal{E} \mathrm{CH}_{4}\left(\mathrm{~kg} \mathrm{CH}_{4} / \mathrm{kg} \mathrm{OS}\right)$ \\
Drijfmest & 0.22 & 0.17 & 0.025 \\
\hline Vaste mest & 0.22 & 0.02 & 0.003 \\
\hline Weidemest & 0.22 & 0.01 & 0.002
\end{tabular}


Wanneer de bovenstaande tabellen worden gecombineerd kunnen onderstaande emissies voor melkvee berekend worden bij een gemiddelde weidegang:

Tabel 4 Berekende $\mathrm{CH}_{4}$-emissie uit mest in $\mathrm{kg} / \mathrm{j}$ per dier in 2013.

\begin{tabular}{lcclc} 
& Melkvee & Jongvee $<1$ jaar & \multicolumn{1}{c}{ Jongvee $>1$ jaar } & 19.6 \\
Drijfmest & 42.8 & 9.9 & 2.3 \\
\hline Vaste mest & 5.1 & 1.2 & 2.3 \\
\hline Weidemest & 3.4 & 0.8 & 1.6 \\
\hline
\end{tabular}

In paragraaf 3.1 werd voor melkkoeien de bijdrage van mest op basis van metingen geschat op $41 \mathrm{~kg} / \mathrm{j}$ per dierplaats. Dat komt goed overeen met de berekende waarde van 42.8 in Tabel 4 Voor het jongvee en voor de emissie uit vaste mest zijn geen validatie-metingen bekend.

Zoals eerder opgemerkt maakt de door IPCC geadviseerde methode geen onderscheid tussen de verschillende opslagen. De waarden gelden voor de som van de opslagen zoals die zich in de praktijk voordoen: in de stal onder de roosters en buiten de stal in mestsilo's. In Nederland betekent dit vooral opslag in de stal. De praktijk leert dat pas op het einde van de winterperiode, vlak voor het uitrijseizoen in februari weer begint, de mestsilo's gevuld gaan worden vanuit de volle mestkelders. De mestsilo's zijn dus maar korte tijd gevuld. 


\section{$4 \quad$ Broeikasgasemissies door vergisten}

Zoals in hoofdstuk 2.1 aangegeven zijn $\mathrm{N}_{2} \mathrm{O}$ emissies klein en de verwachte veranderingen door vergisting niet substantieel. Wanneer we dus praten over broeikasgassen van de vergister en het perspectief van mitigatie hebben we het dus over $\mathrm{CH}_{4}$ in deze publicatie. Mestvergisting wordt gezien als een mogelijke maatregel om de broeikasgasemissies uit mest te reduceren. Door de mest te vergisten kunnen eventuele $\mathrm{CH}_{4}$-emissies uit opgeslagen mest (binnen en buiten de stal) worden vermeden. Door het geproduceerde biogas op te waarderen of in WKK-installaties (Warmtekrachtkoppeling) in warmte en stroom om te zetten, kan het gebruik van fossiele brandstoffen gereduceerd worden. Aandachtspunt is het vermijden van $\mathrm{CH}_{4}$-verliezen tijdens het gehele vergistingsproces (opslag van mest en digestaat, vergister, CHP-installatie of installatie voor het opwaarderen van biogas).

Door de diversiteit aan potentiele verliesbronnen en aan de meetmethoden die toegepast worden om de $\mathrm{CH}_{4}$-emissies uit die bronnen te meten, blijft het bepalen van een vaste factor voor deze $\mathrm{CH}_{4}$ verliezen een grote uitdaging. In Daniel-Gromke et al. (2015) wordt een waarde van $1 \% \mathrm{CH}_{4}$-verlies uit de gehele vergistingsinstallatie voorgesteld. In Oostenrijk wordt voor het inventariseren en rapporteren van de nationale $\mathrm{CH}_{4}$-emissies een waarde van $2 \% \mathrm{CH}_{4}$-verlies bij vergistingsinstallaties toegepast (NIR, 2016). In Martin (2008) wordt geadviseerd om een standaardwaarde van $15 \%$ te gebruiken, terwijl in de IPCC (2006) een standaardwaarde van $10 \%$ wordt voorgesteld voor potentiele verliezen uit vergistingsinstallaties.

Uit het beperkt aantal beschikbare publicaties (Tabel 5) kan geconcludeerd worden dat met name open/niet gasdicht opslagen van digestaat (0,2 - 11,2\%; Liebetrau et al., 2013), overdrukventielen (0,06 - 3,88\%; Holmgren, 2012) en de uitlaatpunten bij WKK-installaties (0,4 - 3,3\%; Liebetrau et al., 2013; Zdanevitch et al., 2014) de belangrijkste $\mathrm{CH}_{4}$-verliesbronnen zijn. Scheiding van digestaat en open opslag van de gescheiden producten kunnen ook hoge $\mathrm{CH}_{4}$-verliezen $(0,13-5,04 \%$; Liebetrau et al., 2013) opleveren. Flesch et al. (2011) geven aan dat, tijdens affakkelen, ingezet wanneer de overdruk in het systeem teveel toeneemt, 10 keer hogere $\mathrm{CH}_{4}$-emissies dan tijdens normale activiteit gemeten kunnen worden. Emissies uit de vergister zelf zijn meestal verwaarlooswaar (0,02 - 0,07\%; Liebetrau et al., 2013; Büeler, 2011). Er zijn geen gegevens gevonden over individuele bepalingen van het $\mathrm{CH}_{4}$-verlies uit een installatie voor het opwaarderen van biogas. De gerapporteerde $\mathrm{CH}_{4}$-verliezen uit een complete vergistingsinstallatie met WKKinstallatie (1,6 - 5,5\%; Flesch et al., 2011; Groth et al., 2015; Hrad et al., 2017) zijn groter dan uit een complete vergistingsinstallatie met een unit voor het opwaarderen van biogas $(0,2-0,5 \%$ voor een combinatie met gasdicht opslag van het digestaat, volgens Westerkamp et al. (2014) en Wolf en Scherello (2013); 0,6-3,0\% voor een combinatie met open opslag van het digestaat, volgens Reinelt et al., 2017). 


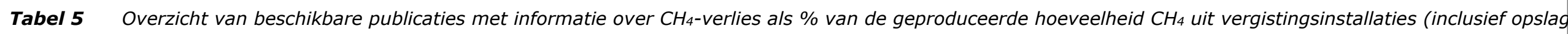
van digestaat en biogasgebruik).

\begin{tabular}{|c|c|c|c|c|c|c|c|}
\hline Referentie & Land & $\begin{array}{c}\text { Aantal } \\
\text { locaties }\end{array}$ & Meetmethode & Meetperiode & Opslag digestaat & Biogasgebruik & $\mathrm{CH}_{4}$-verlies (\%) \\
\hline$[1]$ & Canada & 1 & Remote sensing & $\begin{array}{l}4 \text { seizoenen } \\
\text { ( } 5-7 \text { dagen per seizoen) }\end{array}$ & Open opslag & $\mathrm{CHP}$ & $3,1[1,7: 5,2]$ \\
\hline$[2]$ & Denemarken & 9 & Onbekend & Onbekend & Onbekend & Onbekend & $2,7[0,0: 10,0]$ \\
\hline$[3]$ & Frankrijk & 3 & Onbekend & Onbekend & Onbekend & CHP & $1,7-3,2$ \\
\hline \multirow{6}{*}[4]{} & \multirow{6}{*}{ Duitsland } & 10 & On-site & Onbekend & n.v.t. & $\mathrm{CHP}$ & $0,4-3,28$ \\
\hline & & 2 & On-site & Onbekend & Niet-gasdicht & $\mathrm{CHP}$ & $2,58-10,30$ \\
\hline & & 5 & On-site & Onbekend & Open & $\mathrm{CHP}$ & $0,22-11,22$ \\
\hline & & 8 & On-site & Onbekend & n.v.t. & $\mathrm{CHP}$ & 0,0244 \\
\hline & & 10 & On-site & Onbekend & n.v.t. & $\mathrm{CHP}$ & 0,00065 \\
\hline & & 3 & On-site & Onbekend & n.v.t. & $\mathrm{CHP}$ & $0,135-5,04$ \\
\hline \multirow{2}{*}[5]{} & \multirow{2}{*}{ Duitsland } & 2 & Remote sensing & Onbekend & Gasdicht & Biogasopwaarderen & $0,22-0,51$ \\
\hline & & 1 & Remote sensing & Onbekend & Niet-gasdicht & Biogasopwaarderen & 2,0 \\
\hline \multirow{2}{*}[6]{} & \multirow{2}{*}{ Duitsland } & 1 & On-site & 106 dagen (winter) & n.v.t. & Onbekend & 0,06 \\
\hline & & 1 & On-site & 66 dagen (zomer) & n.v.t. & Onbekend & 3,88 \\
\hline \multirow{2}{*}[7]{} & \multirow{2}{*}{ Zweden } & 18 & Onbekend & Onbekend (2007-2009) & Onbekend & $\mathrm{CHP}$ & 1,6 \\
\hline & & 20 & Onbekend & Onbekend (2007-2009) & Onbekend & Biogasopwaarderen & 2,7 \\
\hline \multirow{2}{*}[8]{} & \multirow{2}{*}{ Zweden } & 1 & Remote sensing & 3 dagen & Open opslag & Biogasopwaarderen & $0,6-3,0$ \\
\hline & & 1 & On-site & 3 dagen & Open opslag & Biogasopwaarderen & $0,6-2,1$ \\
\hline \multirow{3}{*}[9]{} & \multirow{3}{*}{ Oostenrijk } & 1 & Remote sensing & 7 dagen & Open opslag & $\mathrm{CHP}$ & $3,0-4,0$ \\
\hline & & 2 & Remote sensing & 2 metingen van 3-5 uur & Open opslag & $\mathrm{CHP}$ & $3,2-5,5$ \\
\hline & & 2 & Remote sensing & 2 metingen van 3-5 uur & Gasdicht & $\mathrm{CHP}$ & $1,6-5,2$ \\
\hline$[10]$ & Duitsland & 1 & Remote sensing & $1 \mathrm{dag}$ & $\begin{array}{l}1 \text { open en } \\
1 \text { gasdicht opslag }\end{array}$ & $\mathrm{CHP}$ & 3,8 \\
\hline$[11]$ & Duitsland & 1 & Remote sensing & 1 uur & Gasdicht & Biogasopwaarderen & 0,4 \\
\hline$[12]$ & Zwitserland & 1 & On-site & Onbekend & n.v.t. & n.v.t. & $0,04-0,065$ \\
\hline \multirow[b]{2}{*}[13]{} & & 3 & Remote sensing & Onbekend & Onbekend & $\mathrm{CHP}$ & $0,3-6,4$ \\
\hline & & 2 & Remote sensing & Onbekend & Onbekend & Biogasopwaarderen & $2,4-3,3$ \\
\hline
\end{tabular}


[1] Flesch et al. (2011). Digestaat wordt gescheiden. Open opslag voor zowel dunne als dikke fractie.

[2] Hjort-Gregersen (2013).

[3] Zdanevitch et al. (2014). Aangehaald bij Holmgren et al. (2015). Metingen alleen bij CHP-installatie.

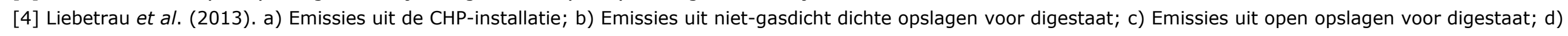
Emissies uit de vergister; e) Emissies uit opslag inkuilen; f) Emissies uit scheidingsinstallatie en opslag

[5] Westerkamp et al. (2014). Aangehaald bij Holmgren et al. (2015).

[6] Reinelt et al. (2016). Emissies uit overdrukventielen.

[7] Holmgren (2012). Aangehaald bij Holmgren et al. (2015).

[8] Reinelt et al. (2017). Metingen zijn door 6 verschillende instituten uitgevoerd.

[9] Hrad et al. (2015) en Hrad et al. (2017).

[10] Groth et al. (2015).

[11] Wolf en Schrello (2013). Aangehaald bij Liebetrau et al. (2017).

[12] Büeler (2011).

[13] Fredenslund en Scheutz (2017). 


\section{$5 \quad$ Koolstofbalans}

De grootste bronnen van $\mathrm{CH}_{4}$ bij vergisting worden veroorzaakt door de opslag van mest en digestaat (Pardo, 2016). Deze auteur concludeert dat het afdekken van opslagen effectief is om $\mathrm{NH}_{3}$ te reduceren, maar ze konden geen significant effect aantonen van afdekken op de emissies van $\mathrm{CH}_{4}$ en $\mathrm{N}_{2} \mathrm{O}$. Dammgen et al.(2012) claimen echter wel een reductie van ca $20 \%$ door afdekking. Rotz en Hafner (2011) vonden in de Verenigde Staten dat de 'mestmeren' die ze daar als opslag hebben (anaerobic lagoons) weliswaar kosteneffectief zijn om mest op te slaan, maar dat door de lange opslagtermijn en het grote oppervlak, hogere $\mathrm{NH}_{3}$ - en $\mathrm{CH}_{4}$-verliezen optreden dan bij mestsilo's. Petersen (2018) beaamt dat de omstandigheden waaronder mest wordt opgeslagen van belang zijn voor de mate van $\mathrm{CH}_{4}$ emissie. Hij benoemt oppervlakte-volume ratio, gasuitwisseling boven het oppervlak (door windsnelheid en/of convectieve warmteproductie) en de dikte van de diffuse grenslaag tussen mest en lucht. Dit heeft volgens Petersen (2018) te maken met de mate waarin $\mathrm{CO}_{2}$ dan wel $\mathrm{CH}_{4}$ ontstaat uit de afbraak van de organische stof, aangezien geen sprake zou zijn van een vaste ratio tussen emissie van $\mathrm{CO}_{2}$ en $\mathrm{CH}_{4}$.

Torrellas et al. (2018) maten aan een vergistingsinstallatie waarbij het digestaat gescheiden werd opgeslagen in een dunne fractie en een dikke fractie. $\mathrm{Zij}$ vonden dat verreweg de hoogste $\mathrm{CH}_{4}$-emissie optrad bij de (open) opslag van de dunne digestaat-fractie. Perazzolo et al. (2017) vonden dat gescheiden fracties van digestaat minder emitteren dan ongescheiden digestaat, en vonden net als Torrellas et al. (2018) dat de dunne fractie meer $\mathrm{C}$, maar ook meer $\mathrm{N}$ emitteerde dan de dikke fractie. Dat dunne fractie meer $\mathrm{CH}_{4}$ kan uitstoten hadden Baldé et al. (2016) ook al ervaren bij mest. Zij veronderstellen dat dat komt omdat met name de dunne fractie de makkelijk afbreekbare organische stof bevat (Vu et al., 2016). Dit pleit er voor om digestaat te scheiden als strategie om BKG te reduceren.

Fangueiro et al. (2008) vonden ook lagere BKG emissies bij gescheiden fracties van mest omdat de totale emissie van $\mathrm{CH}_{4}$ lager was, ondanks dat de dikke fractie van gescheiden mest hoge $\mathrm{N}_{2} \mathrm{O}$ emissies had vanwege het voorkomen van aerobe en anaerobe zones, vergelijkbaar met gestapelde vaste mest. De scheidingsefficiëntie is een belangrijke factor voor lagere broeikasgasemissies van de gescheiden fractie (Van der Zaag et al. (2013). Wanneer mest primair gescheiden wordt, zit het merendeel van de OS in de dikke fractie. Primaire scheiding betekent scheiding in de stal direct na uitscheiding door het dier. Vu et al. (2016) constateerden dat $96 \%$ van de OS in de dikke fractie zat in een varkensstal met mestbanden onder de roosters die een lichte helling hadden waardoor de urine direct af kon lopen. De band met de vaste mest werd regelmatig afgedraaid. De vaste mest ging meteen de vergister in. Dit geeft een hoge $\mathrm{CH}_{4}$-opbrengst en is economisch gunstig, omdat een kleinere reactor nodig is. Dit pleit voor primaire scheiding voordat men gaat vergisten

Maldaner et al. (2018) onderzochten het verschil tussen de emissies van de onbehandelde mest met die van digestaat en vonden dat de $\mathrm{CH}_{4}$-emissies van digestaat $85 \%$ lager waren dan die van mest. Dit was echter niet terug te voeren op het verschil in organische stof in de mest. De correlatie tussen de afbraak van de organische stof en de $\mathrm{CH}_{4}$ emissie was ook laag $(0,37)$. Dat komt omdat de organische stof in het digestaat moeilijker afbreekbaar is. Wel werd aangetoond dat de correlatie tussen temperatuur en $\mathrm{CH}_{4}$ emissie bij digestaat significant hoger was dan bij mest (op $2 \mathrm{~m}$ diepte $0.98, \mathrm{p}<0.001)$.

Pardo (2016) concludeerde dat naast gereduceerde emissies door vervanging van fossiele brandstoffen, de reductie door vergisting met name veroorzaakt werd door verminderde emissie van $\mathrm{CH}_{4}$ uit digestaat en/of mest gedurende opslag. Finnan et al. (2014) voegden daaraan toe dat wanneer digestaat in de zomer werd opgeslagen de emissies wel hoger uit konden komen dan die van ruwe mest. Pardo (2016) berekende dat mestmanagement een belangrijk deel van de nutrientenflows en de BKG emissies bepaalt, ook in de scenario's met vergisting. Dit is in de zomer nog meer het geval dan in de winter (Perazzolo et al., 2017). 
Samenvattend: de mate waarin broeikasgassen emitteren uit mest en digestaat varieert, en hangt af van veel factoren. Groenestein (2006) inventariseerde de volgende mest-gerelateerde factoren, die ook uit bovenstaande studies blijken: OS gehalte, temperatuur, leeftijd van de mest (retentietijd), $\mathrm{O}_{2}$ gehalte, $\mathrm{NH}_{4}{ }^{+}$gehalte, $\mathrm{pH}$ en de $\mathrm{C} / \mathrm{N}$ ratio. De variatie die in voorgaande paragrafen is beschreven en die ontstaat door verschillend mestmanagement (afdekken van opslagen, scheiden van mest, scheiden van digestaat, klimaatomstandigheden) laat onverlet dat door vergisting van mest de totale emissie van broeikasgassen gereduceerd kan worden, mits het management en het ontwerp van vergistingsinstallatie en de digestaatopslag dusdanig is dat ongewenste lekkages en emissiepunten worden voorkomen. Het toont wel aan dat een interpretatie van gerapporteerde reductiepercentages een analyse van het mestmanagement vereist en van de omstandigheden gedurende de experimenten. Of zoals Aguirre-Villegas et al. (2014) het uitdrukken: "Emissies naar de lucht hangen af van lokale condities (bv. temperatuur) en mest-eigenschappen (bv. organische stof), die beïnvloed worden door het te bestuderen systeem. Deze afhankelijkheid maakt het moeilijk om emissiefactoren van eerdere studies bij andere systemen toe te passen en benadrukken het belang van het afmeten van emissiefactoren aan lokale omstandigheden."

Aguirre-Villegas et al. (2014) maakten een C-balans voor een stal met 1000 melkkoeien in de Verenigde Staten met en zonder mestvergister (Figuur 2). Een lekkage van de vergister van $2.8 \%$ was opgenomen. Na de mestvergisting werd het digestaat gescheiden in een vloeibare en dikke fractie. Uiteindelijk vonden zij een reductie van de broeikasgasemissies van $48 \%$ wanneer een vergister in de mestketen geplaatst werd.
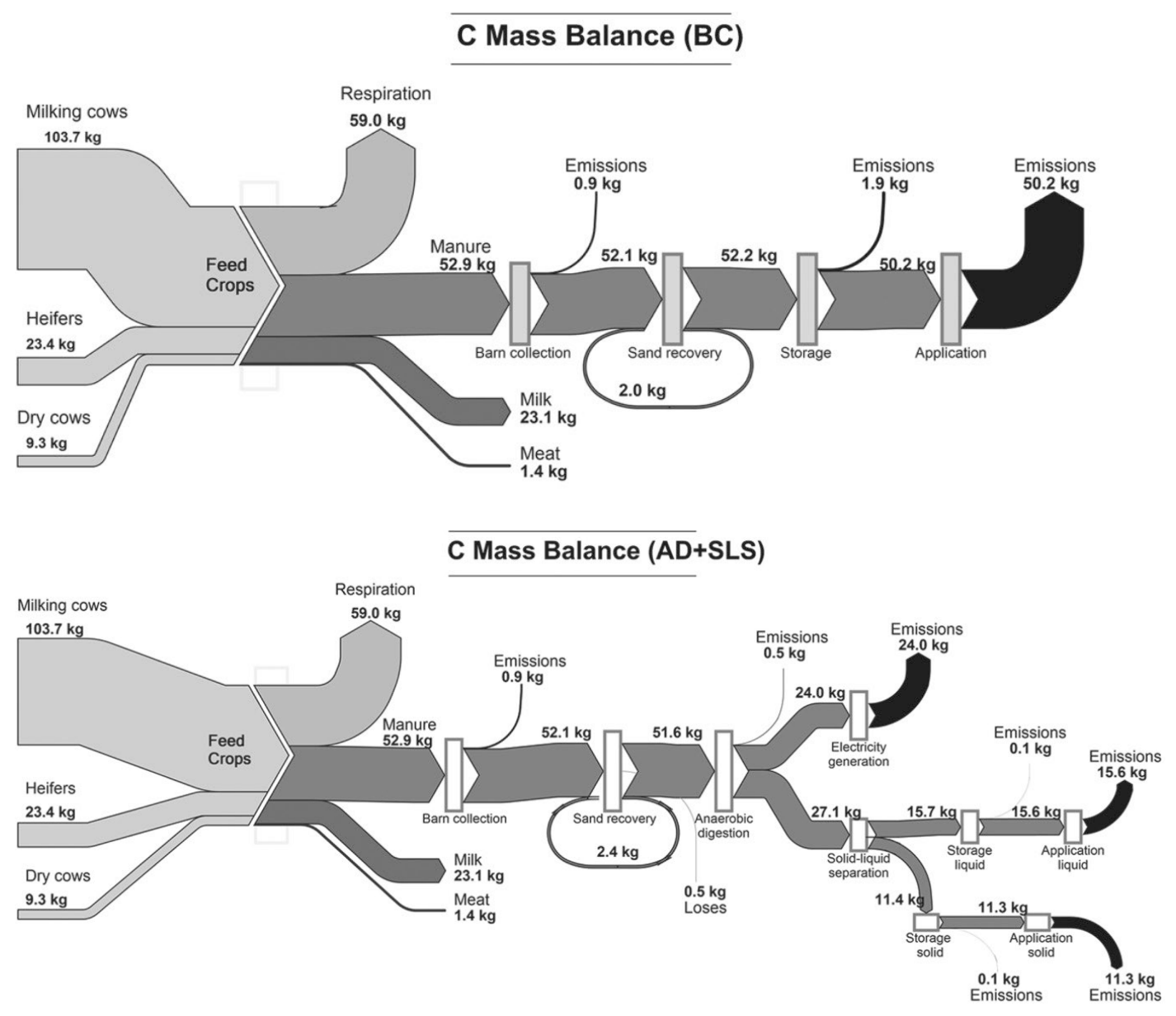

Figuur 2 C massa balans van zonder (boven) en met vergisting inclusief scheiden van digestaat(onder).(AguirreVillegas, 2014). De balans is gebaseerd op 1 ton drijfmest. 
De balans van Aguirre-Villegas et al. (2014) rekent per ton geproduceerde drijfmest en maakt geen onderscheid tussen $\mathrm{CH}_{4}-\mathrm{C}$ en $\mathrm{CO}_{2}-\mathrm{C}$. Ze gaan ervan uit dat geen $\mathrm{C}$ opslag in de bodem plaats vindt en dat dus alles uiteindelijk op het land als $\mathrm{CO}_{2}$ vervluchtigt. Bij bestudering van de massabalans van Aguirre-Villegas et al. (2014) blijkt dat mest dat in de opslag gaat ongeveer evenveel $C$ bevat als de mest die in de vergister gaat. De stal heeft namelijk geen kelder, maar een dichte vloer, ingestrooid met zand. Door de aerobe omstandigheden zijn $\mathrm{CH}_{4}$-emissies uit de stal zelf dus laag. De mest gaat bij de referentie $(B C)$ na de stal 6 maanden in een onafgedekte opslag. $\mathrm{De} \mathrm{NH}_{3}$ emissie blijkt dan ook bijna vier maal zo hoog te zijn als in de Nederlandse situatie, waarbij de opslag wel afgedekt wordt. Uitgaande van een verhouding van $\mathrm{CH}_{4}: \mathrm{CO}_{2}$ van $65: 35 \%$ zou de emissie van $\mathrm{CH}_{4} 43 \mathrm{~kg}$ per aanwezig dier per jaar zijn.

Sefeedpari et al. (2019) maakten een nutriëntenbalans voor een stal met en zonder vergisting. Zij berekenden hoeveel van de initiële nutriënten in het eindproduct terug gevonden werden. Daarvoor introduceerden ze de "Manure Nutrient Recovery Efficiency" (MNRE), die aangeeft in welke mate een nutriënt (inclusief C) uiteindelijk beschikbaar is in de mest die resteert na mestbewerking. In totaal beschouwden ze 8 scenario's:

Sc. 1 is de referentie, een melkveestal met een dichte vloer, ingestrooid met zand;

Sc. 2 werd mest gescheiden;

Sc. 3 werd $50 \%$ van de mest gescheiden, en $50 \%$ gecomposteerd;

Sc. 4 is als Sc. 2 waarbij eerst mest en zand werden gescheiden;

Sc. 5 is als Sc. 3 waarbij eerst mest en zand werden gescheiden;

Sc. 6 werden mest en zand gescheiden, mest vergist, digestaat gescheiden;

Sc. 7 was als 6 , maar werd $50 \%$ van het digestaat gescheiden en $50 \%$ werd gecomposteerd;

Sc. 8 was als Sc. 6 waarbij alle dikke fractie van de digestaat werd gecomposteerd.

Scenario's 6-8 bevatten dus de vergister, waarbij scenario 6 'recht-toe-recht-aan' vergisten is, waarna digestaat gescheiden wordt opgeslagen en Sc. 7 en 8 bevatten nog compostering van de dikke fractie van het digestaat.

Figuur 3 laat zien dat de MNRE voor C met vergisten hetzelfde was als voor de referentie, behalve wanneer de dikke fractie in zijn geheel werd gecomposteerd (Sc. 8), dan was C-verlies groter. Dat betekent dat voor Sc. 6 (vergisting) een zelfde hoeveelheid OS werd omgezet in de vergister, als de hoeveelheid die gedurende opslag werd afgebroken zonder dat sprake was van vergisting (Sc 1 - 5). Dit is ook de situatie die Aguirre-Villegas et al. (2014) beschreef die uitging van een vergelijkbaar mestmanagement in de stal. Het reducerend effect van vergisten op de BKG emissie was gedeeltelijk het effect van het vervangen van fossiele brandstof, maar voor het grootse deel werd dit veroorzaakt doordat de $\mathrm{CH}_{4}$-emissie van de opgeslagen mest lager was. Als toch evenveel OS is afgebroken is gedurende opslag, dan moet een groter aandeel van de $\mathrm{C}$ gebonden als $\mathrm{CO}_{2}$ vervluchtigd zijn t.o.v. de verhoudingen in biogas ( $60 \mathrm{vol} \% \mathrm{CH}_{4}$ en 40 vol\% $\mathrm{CO}_{2}$ ). Dit bevestigt de bevindingen van Petersen et al. (2016) die analyseerde dat het aandeel $\mathrm{CH}_{4}-\mathrm{C}:\left(\mathrm{CH}_{4}-\mathrm{C}+\mathrm{CO}_{2}-\mathrm{C}\right)$ in rundveestallen hoogstens $20 \%$ is, dus niet in dezelfde verhouding als in de vergister (zie ook hoofdstuk 5.5). 


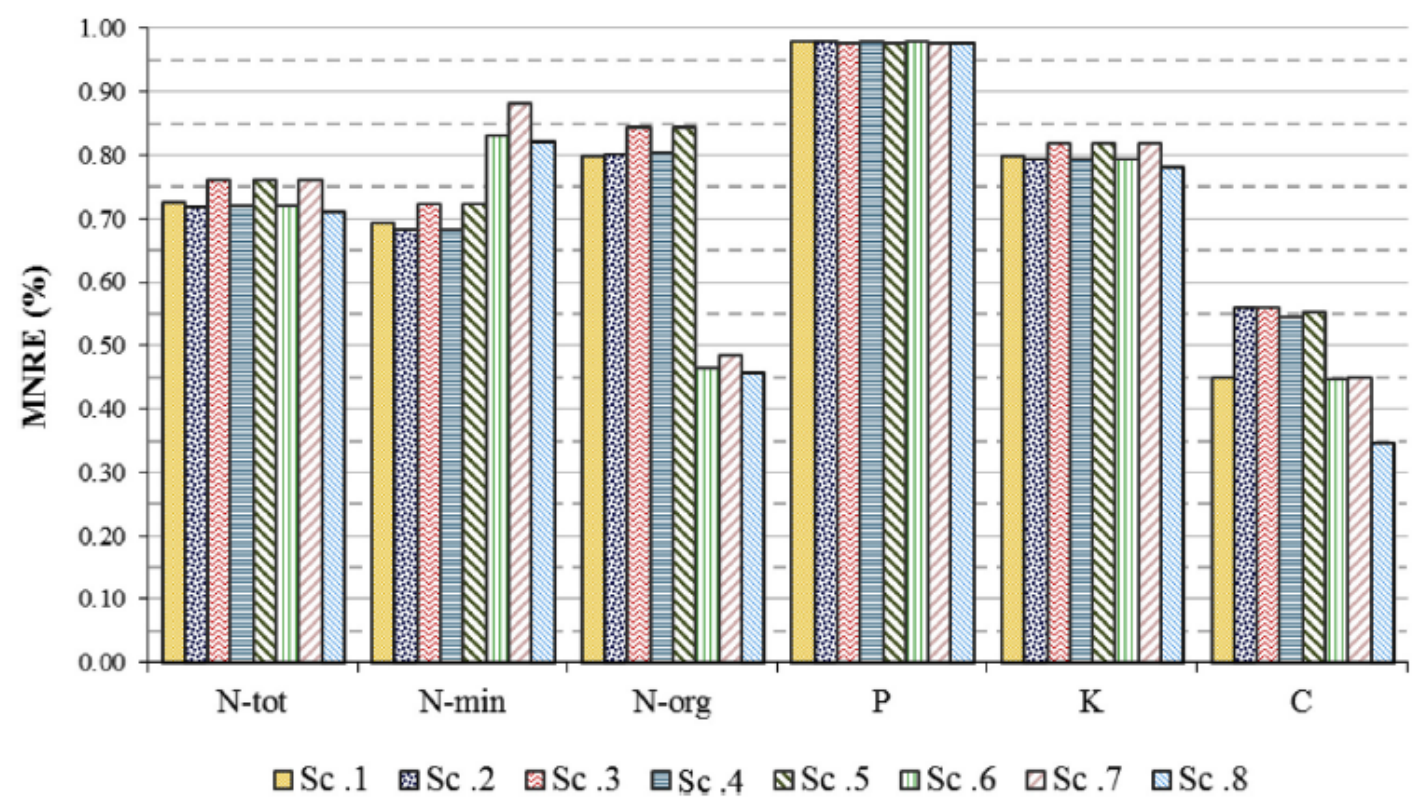

Figuur 3 De Manure Nutrient Recovery Efficiency (MNRE) voor N (totaal, organisch en mineraal), $P, K$ en $C$ op bedrijfsniveau voor verschillendenScenario's (uit Sefeedpari et al., 2019).

Met inachtneming van de uitgangspunten, die niet volledig van toepassing zijn op de Nederlandse situatie, tonen ook de balansstudies van Aguirre Villegas et al. (2014) en Sefeedpari et al. (2019) aan dat vergisting in principe gunstig kan uitpakken voor de totale broeikasgasemissies. Een nadere analyse toegespitst op de Nederlandse situatie is echter gewenst. De waarden van de parameters, zoals eerder genoemd moeten de voor Nederland representatieve waarden bezitten. Daarbij moet bovendien niet alleen gelet worden op de $\mathrm{CH}_{4}$, maar ook op de $\mathrm{CO}_{2}$ als het gaat om de benutting van OS voor de productie van energie, omdat in de stal in verhouding meer $\mathrm{CO}_{2}$ lijkt te ontstaan dan in de vergister. Ondanks dat deze niet bijdraagt aan het versterkte broeikaseffect, vermindert emissie van $\mathrm{CO}_{2}$ wel de $\mathrm{OS}$ in de mest en daarmee de bron van $\mathrm{CH}_{4}$ in de vergister en de hoeveelheid vervangen fossiele brandstof. In Hoofdstuk 5 wordt hier nader op ingegaan met een scenariostudie toegespitst op de Nederlandse situatie en gevoeligheidsanalyses 


\section{$5.1 \quad$ Inleiding}

Zoals in de eerdere hoofdstukken is beschreven, heeft mestvergisting een effect hebben op de stromen van organische stof en koolstof op het bedrijf. Verder kan aangenomen worden dat dit invloed heeft op de emissie van in het bijzonder $\mathrm{CH}_{4}$. Om inzicht te krijgen in de wijze waarop het ontwerp van de stal en het mestvergistingsysteem de koolstofbalans en de emissie van $\mathrm{CH}_{4}$ beïnvloedt, is een aantal scenarioberekeningen uitgevoerd. Hiervoor is gebruik gemaakt van een stofstromenmodel.

\subsection{Beschrijving uitgangspunten scenario's en model}

In het model wordt de mest- en koolstofstromen in een stroomschema verwerkt waarbij rekening gehouden wordt met de omzetting van een deel van de koolstof naar naar $\mathrm{CO}_{2}$ en $\mathrm{CH}_{4}$. Met behulp van het stroomschema worden vervolgens zowel de productie als de emissies van $\mathrm{CH}_{4}$ voor diverse scenario's uitgerekend. De $\mathrm{CH}_{4}$ productie en emissies van $\mathrm{CH}_{4}$ zijn berekend voor zover het mest- en digestaatstromen betreft. Emissies samenhangend met enterische fermentatie zijn buiten beschouwing gelaten.

De scenario's 1 t/m 3 zijn door FrieslandCampina aangeleverd en hebben als doel om een beeld te schetsen welke situaties in de praktijk voorkomen. In Tabel 6 worden de belangrijkste kenmerken van de scenario's en de verschillen daartussen weergegeven.

In de eerste plaats betreft het verschillende bedrijfsgrootten: scenario 1 gaat uit van 260 melkkoeien met een drijfmestproductie van 6.500 ton/jaar, scenario 2 gaat uit van 400 melkkoeien (10.000 ton drijfmest/jaar) en scenario 3 van 540 melkkoeien (13.500 ton drijfmest/jaar). Aangenomen wordt dat de mestsamenstelling gelijk is voor alle scenario's, en dat de samenstelling van het digestaat na de vergisting eveneens gelijk is voor de verschillende scenario's. Scenario 1 en 3 betreffen bedrijven waar de koeien permanent zijn opgestald met een dichte vloer in de stal. In scenario 2 vindt weidegang plaats ( 6 uur per dag, 120 dagen per jaar) en heeft de stal een roostervloer. In de scenario's met de dichte vloer wordt de mest snel uit de stal afgevoerd naar de vergister, zodat er verse mest in de vergister komt (uitgegaan wordt van een gemiddelde opslagduur in de stal van 1 tot 2 weken). In scenario 2 (met de roostervloer) wordt de mest ook frequent uit de stal afgevoerd, maar is de gemiddelde iets langer (3 weken), zodat de mest minder vers is.

In alle gevallen wordt aangenomen dat het biogas (bij benadering) 60 vol\% $\mathrm{CH}_{4}$ en 40 vol\% $\mathrm{CO}_{2}$ bevat. De biogasopbrengst wordt enigszins gevarieerd tussen de scenario's (voor scenario 1 en 3 wordt $38 \mathrm{~m}^{3}$ /ton mest aangenomen, voor scenario 2 wordt $35 \mathrm{~m}^{3} /$ ton mest aangenomen). Ook de opslagduur (of opslagcapaciteit) van het digestaat wordt gevarieerd tussen de scenario's, waarbij vooral de opslagduur in de eerste digestaatopslag van belang is. Voor de eerste digestaatopslag, waar het digestaat vanuit de vergister naar toe wordt gepompt, wordt namelijk aangenomen dat de $\mathrm{CH}_{4}$ die hier nog geproduceerd wordt ('navergisting') niet emitteert maar richting de gasopslag wordt geleid. Wanneer het digestaat daarna vanuit de eerste digestaatopslag naar een tweede of derde digestaatopslag wordt verpompt, word het daar nog geproduceerde biogas niet meer opgevangen maar geëmitteerd.

Bij scenario 1 en 2 wordt de geproduceerde $\mathrm{CH}_{4}$ tenslotte in een WKK (warmte-krachtkoppeling) omgezet in elektriciteit en warmte en wordt de elektriciteit aan het net geleverd; de restwarmte wordt niet gebruikt. In scenario 3 wordt het geproduceerde biogas opgewerkt naar aardgaskwaliteit en als 'groen gas' aan het net geleverd. 


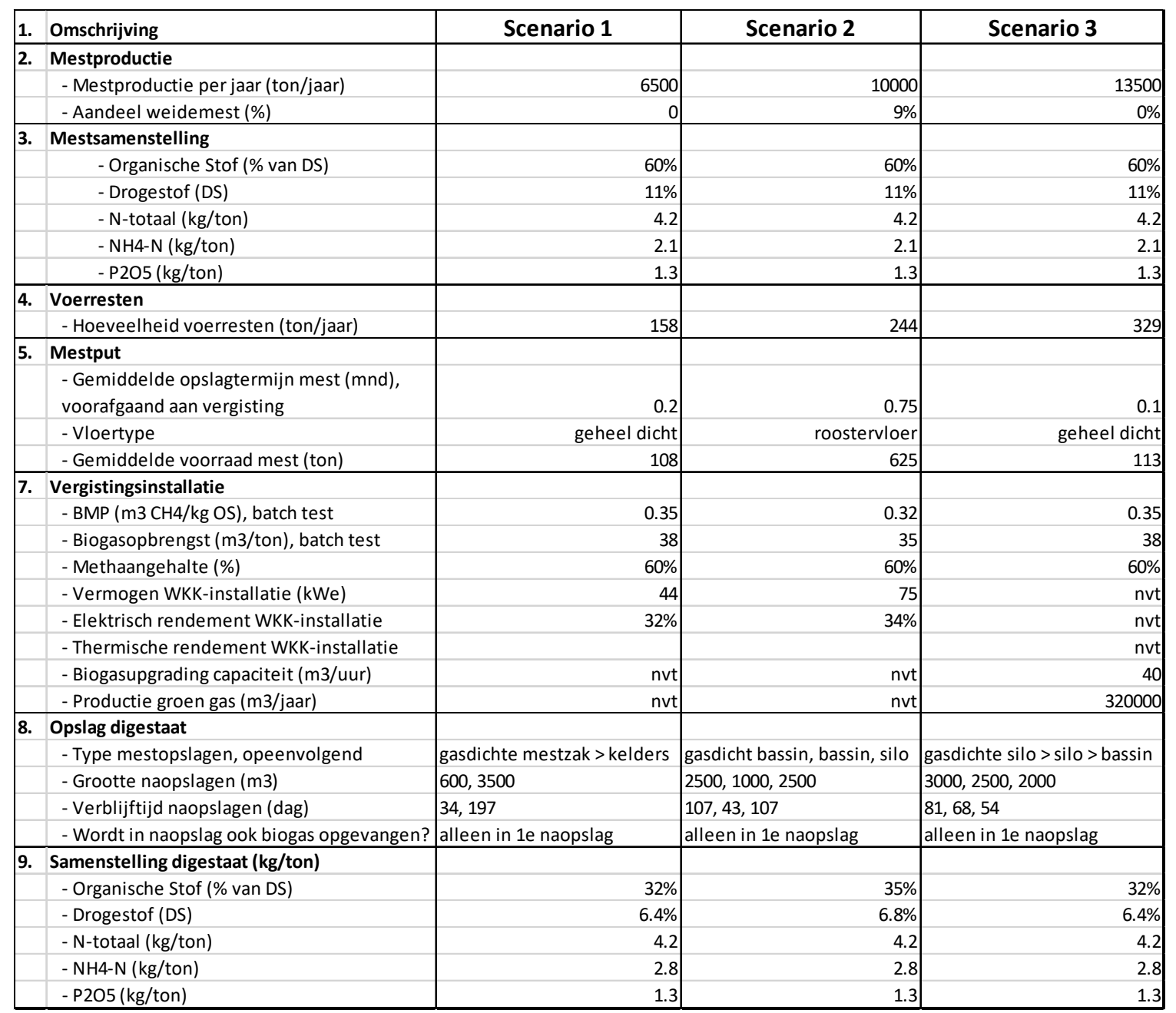

(1) Voor weidegang wordt uitgegaan van 120 dagen, 6 uur per dag; dit komt overeen met de $9 \%$ die in de tabel wordt genoemd voor scenario 2 (120 dagen x 6 uur per dag / 7860 uur per jaar $=9 \%$ ).

Het model gebruikt voor het berekenen van de C-balans en de $\mathrm{CH}_{4}$-emissie uit de mest de uitgangspunten die in Tabel 7 worden weergegeven. In Figuur 4 wordt nader geïllustreerd hoe de $\mathrm{CH}_{4}$-productie afhangt van de opslagduur van de mest in de stal. In Figuur 5 wordt getoond op welke wijze de $\mathrm{CH}_{4}$ productie tijdens opslag van het digestaat afhangt van de opslagduur. In relatie tot Figuur 5 dient bedacht te worden dat de eerste opslag voor digestaat in alle scenario's een gasdichte opslag betreft en dat het hier geproduceerde $\mathrm{CH}_{4}$ wordt opgevangen, net als in de vergister zelf; het $\mathrm{CH}_{4}$ dat in de volgende (tweede en derde) digestaatopslagen wordt geproduceerd, wordt niet opgevangen maar emitteert naar de buitenlucht. Tenslotte wordt in Figuur 6 de samenstelling van de drijfmest geïllustreerd; voor het grootste deel bestaat deze uit water en slechts een klein deel betreft organische stof en mineralen. In het model wordt aangenomen dat $47 \%$ van de organische stof (OS) in de mest koolstof (C) is (Reijs, 2007). Wanneer het DS-gehalte van de mest $11 \%$ (110 kg/ton) en het OS-gehalte $60 \%$ van de DS $(0.60$ $x 110=66 \mathrm{~kg} /$ ton) bedraagt, is het $C$ gehalte $0.47 \times 66=31 \mathrm{~kg} / \mathrm{ton}$. 
Mestopslag in stal

\section{Weidegang}

Vergister

Na-opslag

- $\mathrm{CH}_{4}$ productie is evenredig met opslagduur in stal, waarbij een MCF $=17 \%$ ${ }^{1}$ ) wordt aangenomen voor een opslagcapaciteit van 6 maanden

- Alle geproduceerde $\mathrm{CH}_{4}$ wordt geëmitteerd

- MCF $=1 \%\left({ }^{2}\right)$

- Alle geproduceerde $\mathrm{CH}_{4}$ wordt geëmitteerd

- $\mathrm{CH}_{4}$ productie tot realisatie van $96 \%$ van $\mathrm{BMP}$ van verse mest

- Lekkage van $\mathrm{CH}_{4}$ bedraagt $3 \%$ van productie $\left({ }^{3}\right)$

- Lekkage WKK (slip) bedraagt $1 \%$ van productie $\left(^{3}\right.$ )

- $\mathrm{CH}_{4}$ productie tot realisatie van maximaal $100 \%$ van BMP van verse mest, afhankelijk van opslagduur (zie Figuur 5)

- Lekkage van $\mathrm{CH}_{4}$ bedraagt $3 \%$ van productie

(1) Groenestein et al., 2016; ( $\left.{ }^{2}\right)$ (Lagerwerf et al., 2019); ( $\left.{ }^{3}\right)$ Totale emissie van 4\% is gebaseerd op Hjort-Gregersen (2014).

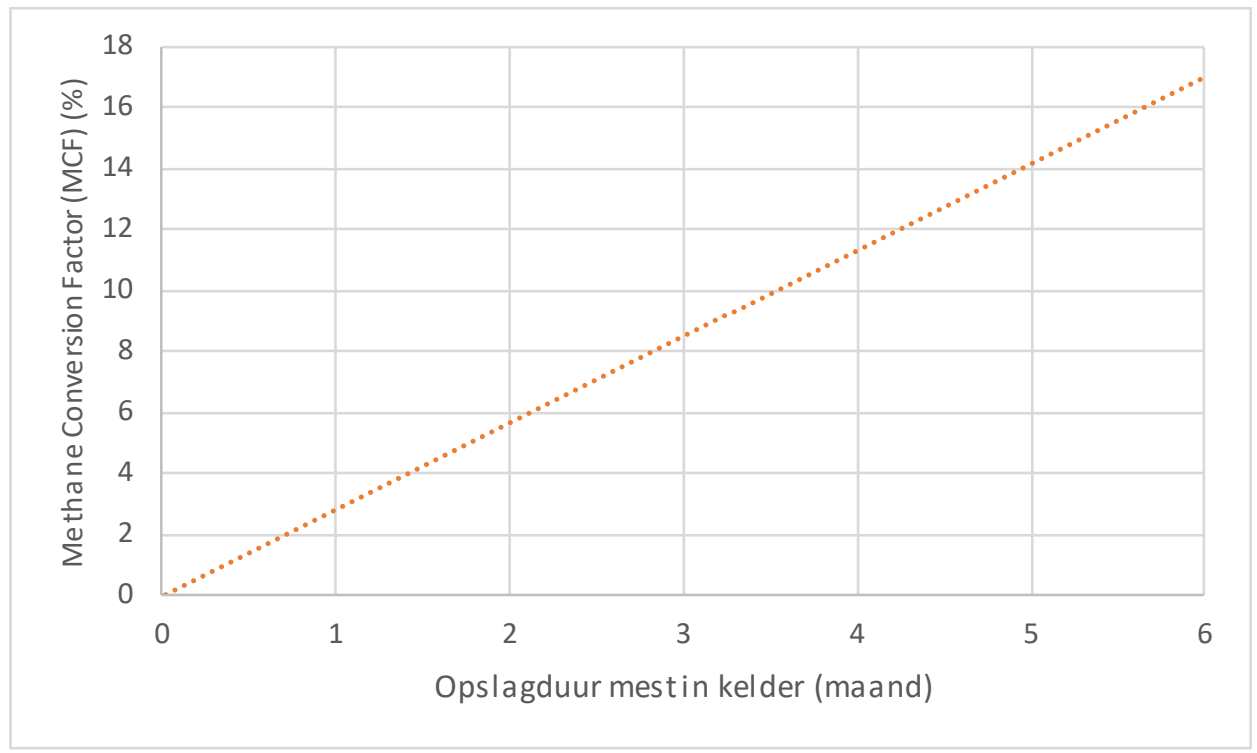

Figuur 4 Methane Conversion Factor (MCF), zoals deze afhangt van de opslagduur; aangenomen wordt dat de MCF recht evenredig toeneemt van $0 \%$ tot $17 \%$ bij een opslagduur van 6 maanden.

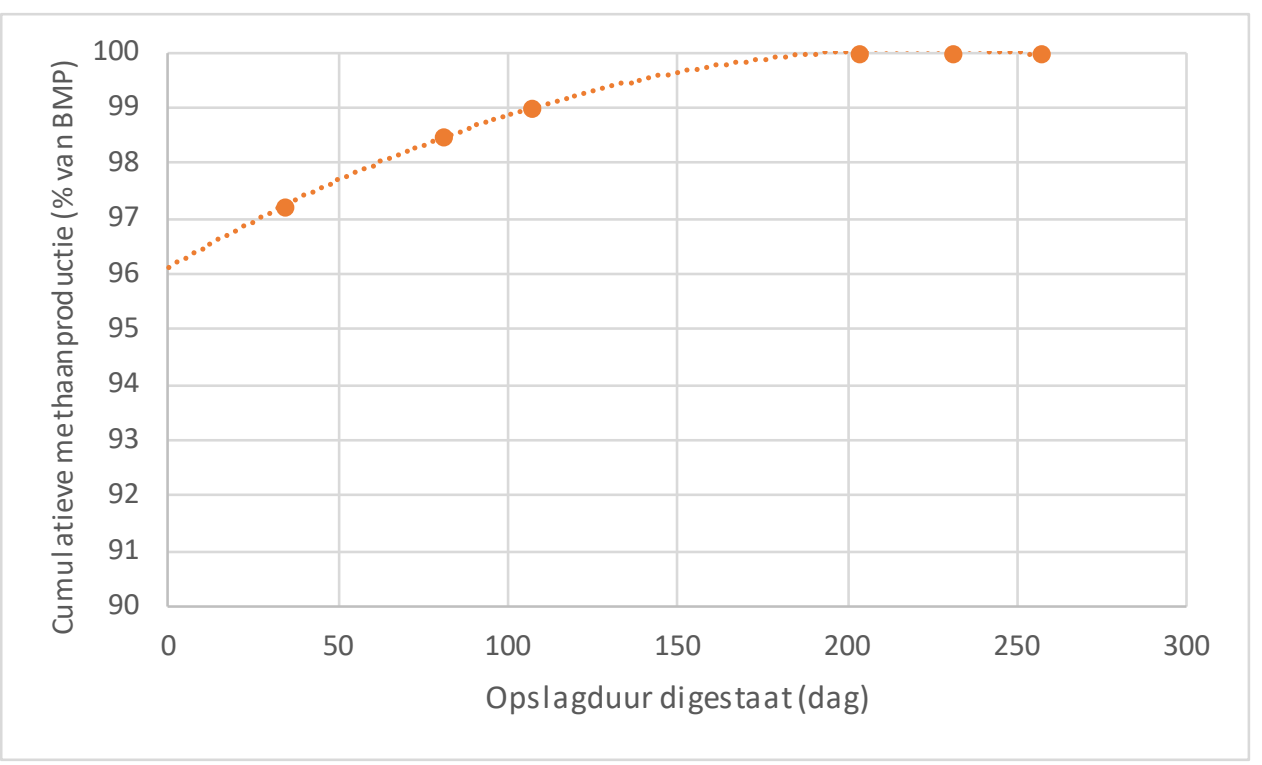

Figuur 5 


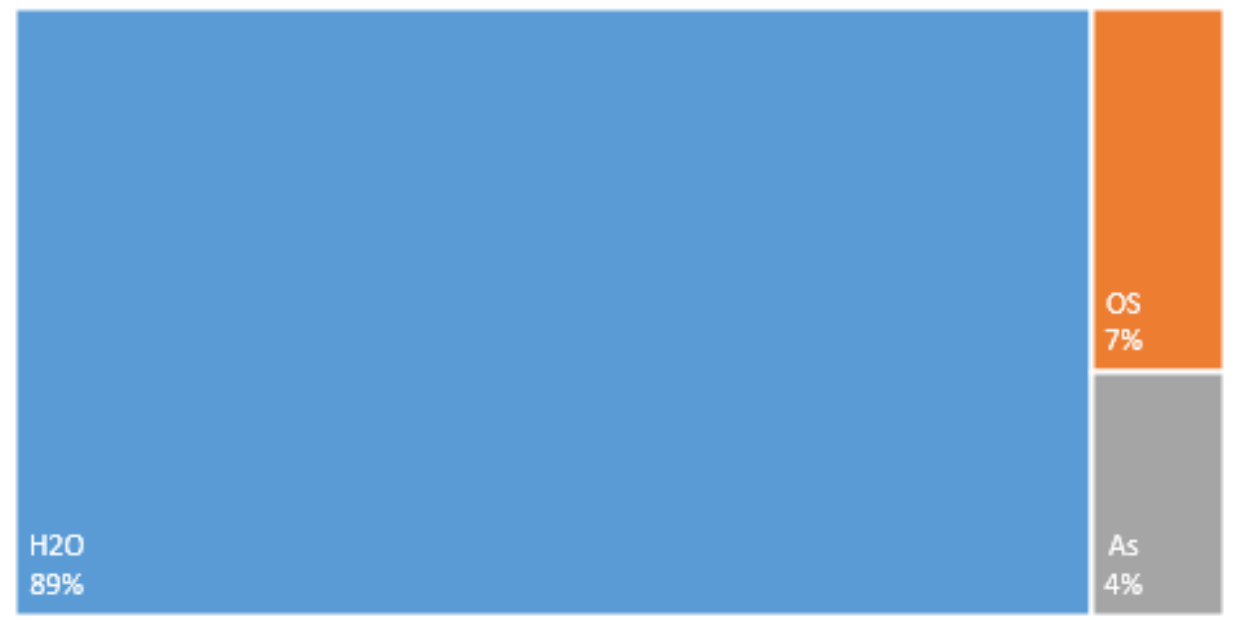

Figur 6 Samenstelling rundveedrijfmest (zie Tabel 6). Het aanwezige de N-org bevindt zich in de fractie organische stof (OS); het aanwezige kalium en fosfor bevindt zich in de asrest; het koolstof bevindt zich (hoofdzakelijk) in de OS fractie. Bedacht moet worden dat tijdens het droogproces van de laboratoriumanalyse een deel van de organische verbindingen en de $\mathrm{NH}_{4}^{+}-\mathrm{N}$ zal vervluchtigen.

Voor de emissiereductie van $\mathrm{CO}_{2}$ die gepaard gaat met het opwekken van 'groene elektriciteit' in de WKK installatie in plaats van productie uit fossiele brandstof, wordt een factor van $721 \mathrm{~g} \mathrm{CO}_{2} / \mathrm{kWhe}$ aangenomen. Dat is de zogenaamde full scope carbon footprint waarde van grijze elektriciteit in Nederland conform de PEF datasets. Voor de productie van opgewerkt 'groen gas' ter vervanging van aardgas wordt een vermeden emissie van $75 \mathrm{~g} \mathrm{CO}_{2}$-eq/MJ gehanteerd. Deze $75 \mathrm{~g} \mathrm{CO}$-eq/MJ is een optelsom van 18,7 $\mathrm{g} \mathrm{CO}_{2}$-eq/MJ als carbon footprint voor de productie van aardgas en $56,50 \mathrm{~g} \mathrm{CO} / \mathrm{MJ}$ dat vrijkomt bij de verbranding.

\subsection{Resultaten scenario-berekeningen}

De uitkomsten van de berekeningen voor de verschillende scenario's kunnen vergeleken worden met een referentiescenario zonder vergisting. Zoals reeds aangegeven in Tabel 7 wordt in reguliere stalsystemen met roostervloeren en opslag van mest onder de vloer een MCF van $17 \%$ gehanteerd, uitgaand van een mestopslagcapaciteit van 6 maanden. Deze situatie wordt gehanteerd als referentiescenario, waarbij de andere waarden (percentage weidemest en BMP waarde van verse mest) in de vergelijking tussen de berekende vergistingsscenario's en de referentiescenario's zonder vergisting gelijk worden gehouden. Dit betekent dat elk van de scenario's $1 \mathrm{t} / \mathrm{m} 3$ zijn eigen referentiescenario heeft. Ook voor de referentiescenario's geldt dat de productie en emissie van $\mathrm{CH}_{4}$ beperkt wordt tot de mest- en digestaatstromen en dat enterische fermentatie buiten beschouwing wordt gelaten.

In Tabel 8 worden de resultaten van de scenarioberekeningen weergegeven. 


\begin{tabular}{|c|c|c|c|c|c|c|}
\hline & \multicolumn{2}{|l|}{ Scenario 1} & \multicolumn{2}{|l|}{ Scenario 2} & \multicolumn{2}{|l|}{ Scenario 3} \\
\hline & $\begin{array}{l}\text { met } \\
\text { vergisting }\end{array}$ & $\begin{array}{l}\text { referentie } \\
\text { zonder } \\
\text { vergisting }\end{array}$ & $\begin{array}{l}\text { met } \\
\text { vergisting }\end{array}$ & $\begin{array}{l}\text { referentie } \\
\text { zonder } \\
\text { vergisting }\end{array}$ & $\begin{array}{l}\text { met } \\
\text { vergisting }\end{array}$ & $\begin{array}{l}\text { referentie } \\
\text { zonder } \\
\text { vergisting }\end{array}$ \\
\hline \multicolumn{7}{|l|}{ Resultaten $\mathrm{CH}_{4}$ emissie ( $\mathrm{kg} \mathrm{CH}_{4} /$ ton mest): } \\
\hline Stal/vloer: & 0.10 & 2.95 & 0.31 & 2.48 & 0.05 & 2.95 \\
\hline Weidegang: & 0.00 & 0.00 & 0.01 & 0.01 & 0.00 & 0.00 \\
\hline Vergister: & 0.66 & nvt & 0.55 & nvt & 0.50 & nvt \\
\hline Eerste naopslag: & 0.01 & nvt & 0.02 & nvt & 0.01 & nvt \\
\hline Tweede naopslag: & 0.32 & nvt & 0.10 & nvt & 0.17 & nvt \\
\hline Totaal: & 1.09 & 2.95 & 0.98 & 2.49 & 0.73 & 2.95 \\
\hline Uitgedrukt als $\mathrm{kg} \mathrm{CH}_{4}$ per melkkoe per jaar: & 27 & 74 & 25 & 62 & 18 & 74 \\
\hline Uitgedrukt als $\mathrm{kg} \mathrm{CH}_{4}$ per $1000 \mathrm{~kg}$ meetmelk: & 2.7 & 7.2 & 2.4 & 6.1 & 1.8 & 7.2 \\
\hline \multicolumn{7}{|l|}{ Emissiereductie t.o.v. referentiescenario: } \\
\hline Emissiereductie $\mathrm{CH}_{4}$ : & $63 \%$ & & $61 \%$ & & $75 \%$ & \\
\hline Emissiereductie $\mathrm{CH}_{4}$ (ton CO2-eq/jaar): & 411 & & 514 & & 1018 & \\
\hline $\begin{array}{l}\text { Vermeden } \mathrm{CO}_{2} \text { door opwekking elektra met WKK } \\
\text { resp. productie 'groen gas' (ton } \mathrm{CO}_{2} \text {-eq/jaar): }\end{array}$ & 352 & & 485 & & 882 & \\
\hline Totaal: & 763 & & 999 & & 1899 & \\
\hline \multicolumn{7}{|l|}{ Productie elektra resp. biogas: } \\
\hline $\begin{array}{l}\text { Methaan productie, beschikbaar voor WKK of } \\
\text { opwerking }\left(\mathrm{m}_{3} \mathrm{CH}_{4} / \mathrm{jaar}\right) \text { : }\end{array}$ & 156,220 & & 202,701 & & 333,302 & \\
\hline Opgewekte elektriciteit met WKK (MWhe/jaar): & 488 & & 673 & & nvt & \\
\hline
\end{tabular}

${ }^{1}$ ) Aangenomen wordt dat de mestproductie 25 ton/jaar per melkkoe bedraagt; uitgegaan wordt van $8687 \mathrm{~kg}$ meetmelk per melkkoe per jaar; emissies worden voor $85 \%$ gealloceerd aan productie van melk- en voor $15 \%$ aan productie van vlees. ${ }^{2}$ ) Voor de vermeden fossiele $\mathrm{CO}_{2}$ emissie wordt $721 \mathrm{~g} \mathrm{CO}_{2}$-eq/kWhe bij opwekking van elektra (WKK) en $75 \mathrm{~g} \mathrm{CO}_{2}$-eq/M] bij productie van 'groen gas' gehanteerd.

$\left({ }^{3}\right)$ Als greenhouse warming potential (GWP) voor $\mathrm{CH}_{4}$ wordt 34 gehanteerd conform de PEFCR Guidance (EC, 2018). $\left({ }^{4}\right)$ In de referentiescenario's is geen sprake van vergisting, maar wordt de mest langdurig onder de stal opgeslagen $(\mathrm{MCF}=17 \%)$ en is geen sprake van externe mestopslag. Alleen de emissie uit de stal en eventueel uit de weide wordt dus meegenomen. De overige uitgangspunten zijn gelijk.

Uit Tabel 8 blijkt dat alle drie de scenario's een aanzienlijke emissiereductie van $\mathrm{CH}_{4}$ tot gevolg hebben in vergelijking tot een referentiescenario zonder mestvergisting, waarbij sprake is van langdurige opslag van mest in de stal (opslagcapaciteit 6 maanden). De belangrijkste reden hiervoor is dat door de aanzienlijk kortere opslagduur in de stal, de emissie van $\mathrm{CH}_{4}$ uit de stal grotendeels achterwege blijft in de vergistingsscenario's.

Verder blijkt dat de $\mathrm{CH}_{4}$-emissie van scenario 1 hoger is dan van de andere twee scenario's. Het verschil tussen scenario 1 en 2 wordt enerzijds veroorzaakt doordat in scenario 2 een deel van de mest $(9 \%)$ in de weide terecht komt, waardoor deze mest relatief weinig emitteert. Wanneer de mest niet in de weide maar in de vergister terecht komt, heeft de hoge $\mathrm{CH}_{4}$-productie in combinatie met optredende lekkage een hoger emissie tot gevolg. Verder is de BMP van scenario 1 hoger $\left(0,35 \mathrm{~m}^{3}\right.$ $\left.\mathrm{CH}_{4} / \mathrm{kg} \mathrm{OS}\right)$ dan bij scenario $2\left(0,32 \mathrm{~m}^{3} \mathrm{CH}_{4} / \mathrm{kg}\right.$ OS) en is de opslagduur van de eerste digestaatopslag - waarbij het geproduceerde $\mathrm{CH}_{4}$ wordt opgevangen- bij scenario 1 korter (34 versus 107 dagen). Beide hebben een verhoging van de $\mathrm{CH}_{4}$-emissie tot gevolg. Alles bij elkaar heeft dit een grotere invloed dan de lagere emissie die bij scenario 1 uit de stal optreedt, als gevolg van de kortere opslagduur voorafgaand aan vergisting (0,20 versus 0,75 maanden).

De emissie van scenario 3 is nog weer lager dan die van scenario 2. De belangrijkste reden daarvoor is de lagere emissie die bij scenario 3 uit de stal optreedt, als gevolg van de kortere opslagduur voorafgaand aan vergisting (0,10 versus 0,75 maanden). De hogere emissie uit de mestopslag (want korter opslagduur in eerste mestopslag) en de hogere emissie uit de vergister zelf (want geen weidemest) wegen hier niet tegen op.

Tenslotte volgt uit Tabel 8 dat de impact van de emissiereductie van $\mathrm{CH}_{4}$ en het voorkomen van de $\mathrm{CO}_{2}$ emissie uit fossiele brandstof (door opwekking van 'groene energie') van een gelijke ordegrootte zijn. 
Eveneens is in het model berekend welke hoeveelheid koolstof uit mest wordt afgebroken, dat wil zeggen, als gevolg van het vergistingsproces is omgezet in $\mathrm{CH}_{4}$ en $\mathrm{CO}_{2}$. Dit wordt weergegeven in Tabel 9. Uit Tabel 9 volgt dat in de referentiescenario's, waarbij de mest 6 maanden in de mestkelder blijft, het $C$ gehalte met ruim 50\% afneemt van 66 naar 30-31 kg/ton. In de vergistingsscenario's neemt het $\mathrm{C}$ gehalte met ruim $75 \%$ af naar $13-15 \mathrm{~kg} / \mathrm{ton}$.

Tabel 9 Berekend gehalte koolstof $(C)$ van verse mest en van digestaat dat na vergisting resteert voor verschillende vergistingsscenario's - monovergisting op melkveebedrijf.

\begin{tabular}{|l|c|c|c|c|c|c|c|}
\hline \multirow{2}{*}{} & \multirow{2}{*}{$\begin{array}{l}\text { Verse } \\
\text { mest }\end{array}$} & \multicolumn{5}{|c|}{ Digestaat } \\
\cline { 3 - 7 } & & \multicolumn{2}{|c|}{ Scenario 1 } & \multicolumn{2}{|c|}{ Scenario 2 } & \multicolumn{2}{l|}{ Scenario 3 } \\
\cline { 3 - 7 } & $\begin{array}{l}\text { met } \\
\text { vergisting }\end{array}$ & $\begin{array}{l}\text { referentie } \\
\text { zonder } \\
\text { vergisting }\end{array}$ & $\begin{array}{l}\text { met } \\
\text { vergisting }\end{array}$ & $\begin{array}{l}\text { referentie } \\
\text { zonder } \\
\text { vergisting }\end{array}$ & $\begin{array}{l}\text { met } \\
\text { vergisting }\end{array}$ & $\begin{array}{l}\text { referentie } \\
\text { zonder } \\
\text { vergisting }\end{array}$ \\
\hline $\begin{array}{l}\text { C-gehalte } \\
\text { (kg/ton) }\end{array}$ & 66 & 13 & 30 & 15 & 31 & 13 & 31 \\
\hline
\end{tabular}

\subsection{Gevoeligheidsanalyse}

Omdat het vergelijken van de verschillende scenario's complex is vanwege het feit dat er telkens meerdere factoren veranderen, wordt met behulp van een gevoeligheidsanalyse onderzocht op welke wijze de belangrijkste uitgangspunten (modelparameters) invloed hebben op de productie en emissie van $\mathrm{CH}_{4}$. De gevoeligheidsanalyse wordt uitgevoerd op scenario 2 met roostervloer, drie weken opslag van mest in de stal en 720 uur weidegang. In het model zijn het aandeel weidemest, de duur van de mestopslag in de stal, de optredende lekkage van biogas uit de vergistingsinstallatie en de verblijftijd in de eerste digestaatopslag van directe invloed op de emissie van $\mathrm{CH}_{4}$.

In Tabel 10 wordt aangegeven in welke mate een verdubbeling of halvering van de individuele modelparameters een effect heeft op de $\mathrm{CH}_{4}$-emissie, op het elektrisch vermogen ( $\mathrm{kWe}$ ) dat in een WKK kan worden opgewekt (op basis van de $\mathrm{CH}_{4}$-productie minus de $\mathrm{CH}_{4}$-emissies) en op de carbon footprint die berekend is als de resultante van enerzijds de verhogende impact van $\mathrm{CH}_{4}$-emissie en anderzijds de vermeden $\mathrm{CO}_{2}$-emissie als gevolg van de opwekking van 'groene elektriciteit'.

Tabel 10 Gevoeligheidsanalyse van scenario-berekeningen voor mono-vergisting op melkveebedrijf.

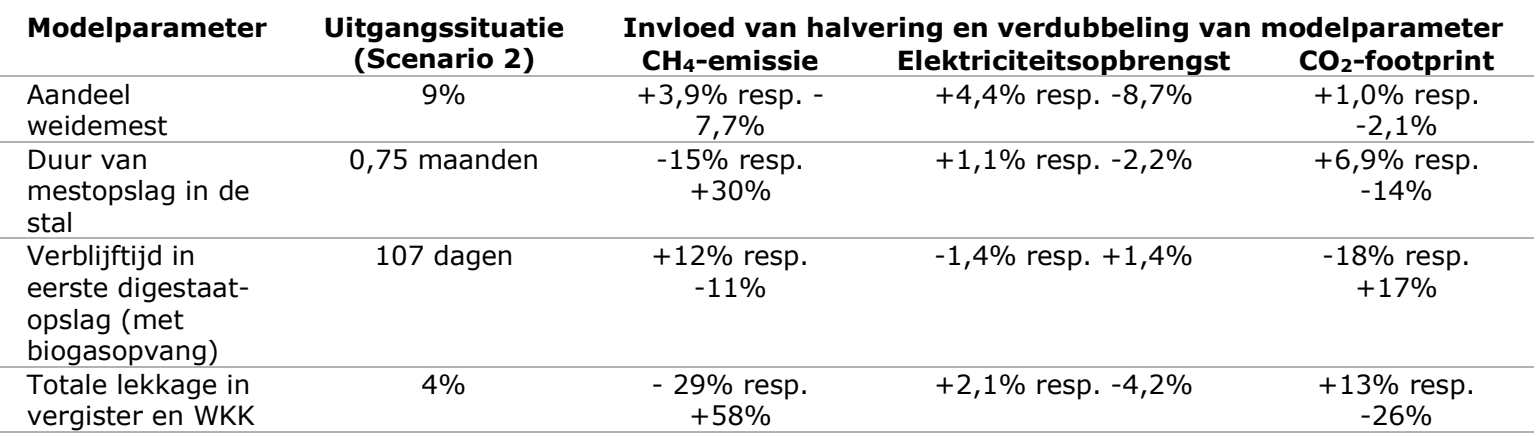

In Figuur 9 t/m 12 wordt voor deze parameters nog eens grafisch weergegeven wat de invloed van op de berekende $\mathrm{CH}_{4}$-emissie en elektriciteitsopbrengst is. Het opgewekte elektrisch vermogen wordt in Figuur 9 t/m 12 uitgedrukt als kWe op basis van de productie over een heel jaar (8.760 uur). In de praktijk zal de WKK installatie altijd groter worden gedimensioneerd aangezien de installatie een aantal uren per jaar niet zal draaien als gevolg van onderhoud of storingen e.d.. Wanneer uitgegaan 
wordt van bijvoorbeeld 7.000 draaiuren per jaar, is voor een berekende kWe opbrengst van $50 \mathrm{kWe}$ een WKK installatie nodig met een capaciteit van $50 \times 8.760 / 7.000=63 \mathrm{kWe}$.

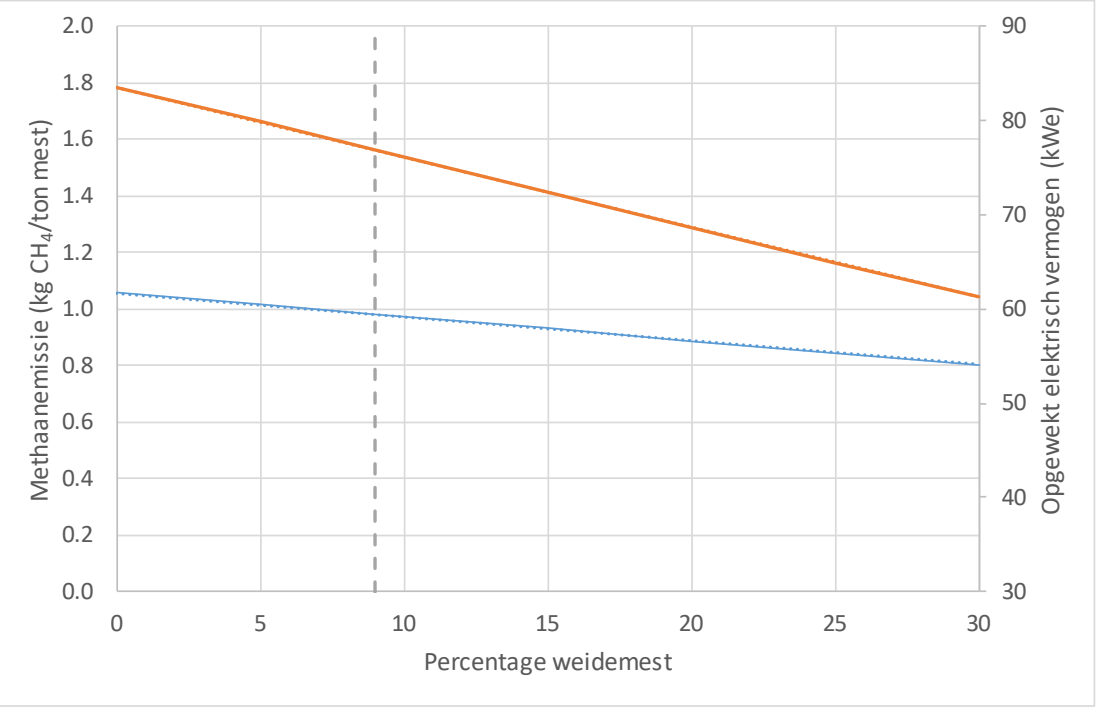

Figur 9 Invloed van weidegang op $\mathrm{CH}_{4}$-emissie (blauw) en opgewekt elektrisch vermogen (oranje). Referentie-situatie: Scenario 2 met 9\% weidegang (verticale stippellijn).

Uit Figuur 9 volgt dat toename van de hoeveelheid weidemest leidt tot een verlaging van zowel de $\mathrm{CH}_{4}$-emissie en de elektra-opbrengst. De verklaring hiervoor is dat hoe meer weidemest geproduceerd wordt, hoe minder mest in de stal terecht komt en naar de vergister gaat. Aangezien aangenomen wordt dat de $\mathrm{CH}_{4}$-emissie in de weide laag is ( $\mathrm{MCF}=1 \%$ ), betekent minder mest in stal en vergister dat er daar minder $\mathrm{CH}_{4}$ wordt geproduceerd en dat dientengevolge ook de daar optredende emissies lager zijn.

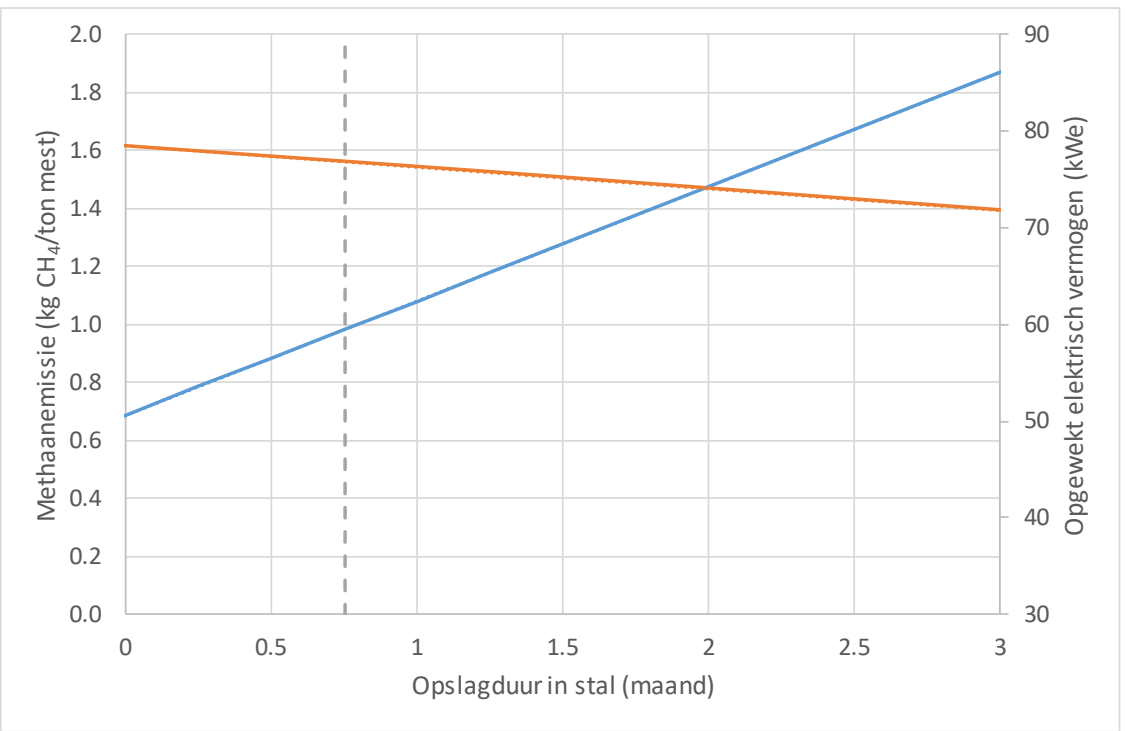

Figuur 10 Invloed van duur van mestopslag in stal (voorafgaand aan vergisting) op emissie van $\mathrm{CH}_{4}$ (blauw) en opgewekt elektrisch vermogen (oranje) bij $\mathrm{CH}_{4}: \mathrm{CO}_{2}=60$ vol\%: 40 vol\%. Referentie-situatie: Scenario 2 met 0,75 maanden opslag (verticale stippellijn). 
Uit Figuur 10 volgt dat een langere mestopslag in de stal, dus voordat de mest naar de vergister gaat, leidt tot een toename van de $\mathrm{CH}_{4}$-emissie en een afname van de elektra-opbrengst. De verklaring hiervoor is dat de langere opslag tot een hogere $\mathrm{CH}_{4}$-emissie uit de stal leidt, aangezien aangenomen wordt dat de emissie uit de stal recht evenredig is met de opslagduur. Doordat reeds een deel van de organische stof uit de mest in de stal wordt omgezet in $\mathrm{CH}_{4}$ en daar emitteert, is de biogasopbrengst van de vergister lager en dus ook de elektra-productie.

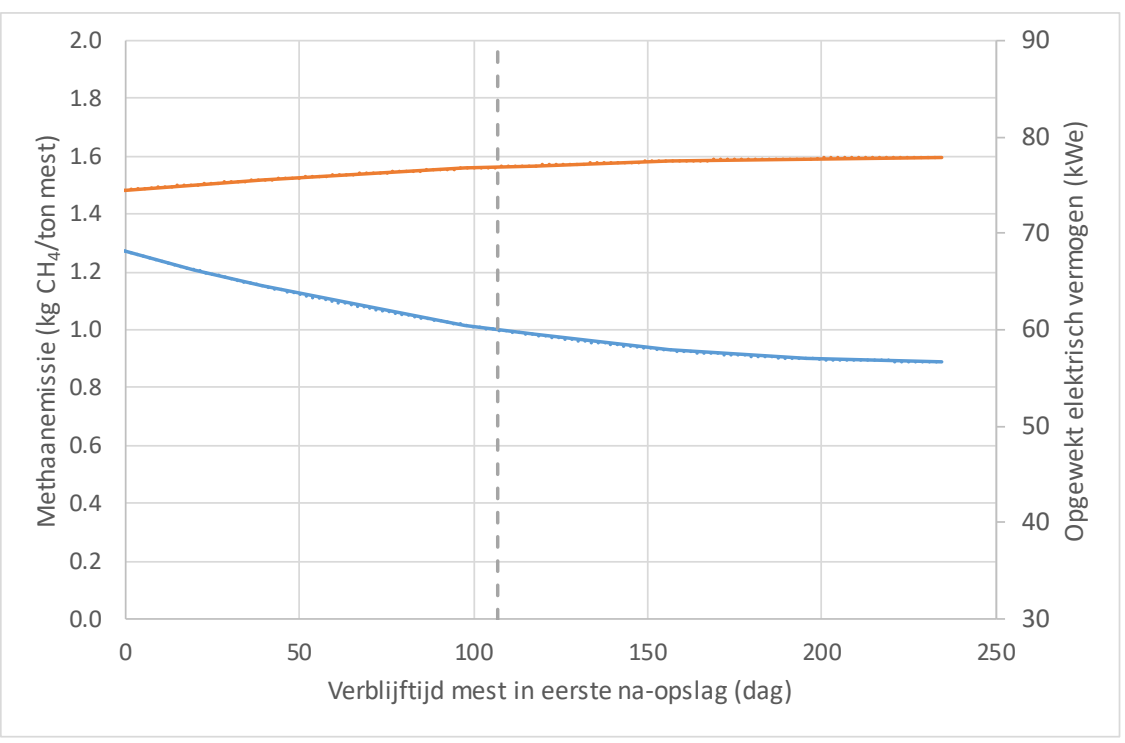

Figuur 11 Invloed van grootte digestaatopslag met gasopvang op emissie van $\mathrm{CH}_{4}$ (blauw) en opgewekt elektrisch vermogen (oranje) bij $\mathrm{CH}_{4}: \mathrm{CO}_{2}=60 \mathrm{vol} \%: 40 \mathrm{vol} \%$. Referentie-situatie: Scenario 2 met 107 dagen opslag (verticale stippellijn).

Uit Figuur 11 volgt dat hoe groter de gasdichte eerste digestaatopslag is, hoe lager de $\mathrm{CH}_{4}$-emissie en hoe hoger de elektra-opbrengst is. Bedacht moet worden dat de $\mathrm{CH}_{4}$-productie niet stopt nadat het digestaat van de vergister naar de digestaatopslag wordt gepompt, maar nog steeds doorgaat (zie Figuur 5). In de eerste digestaatopslag wordt het geproduceerde $\mathrm{CH}_{4}$ echter niet geëmitteerd maar opgevangen, terwijl het $\mathrm{CH}_{4}$ tijdens de volgende digestaatopslagen wel emitteert. Dus hoe langer het digestaat zich bevindt in een gasdichte opslag, hoe lager de emissie en hoe hoger de totale biogasopbrengst is, totdat het maximum is bereikt bij ca. 200 dagen. De hoger biogasopbrengst leidt ten slotte weer tot een hogere elektra-productie in de WKK installatie. 


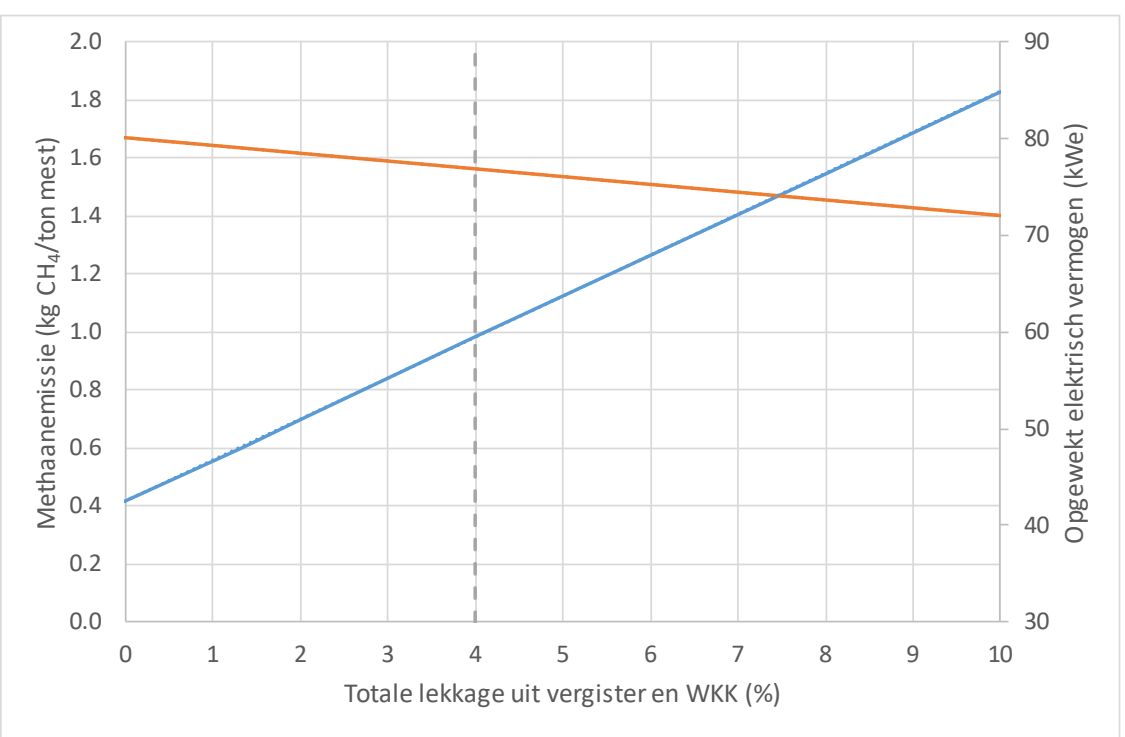

Figuur 12 Invloed van lekkage van $\mathrm{CH}_{4}$ uit vergister en WKK (slip) op totale $\mathrm{CH}_{4}$-emissie (blauw) en opgewekt elektrisch vermogen (oranje). Referentie-situatie: Scenario 2 met in totaal $4 \%$ lekkage, t.w. 3\% uit vergister en $1 \%$ uit WKK (verticale stippellijn).

Tenslotte volgt uit Figuur 12 hoe optredende lekkage uit de vergistingsinstallatie de emissie van $\mathrm{CH}_{4}$ en de elektraopbrengst beïnvloedt. Hoe meer $\mathrm{CH}_{4}$ weglekt uit de installatie, hoe minder $\mathrm{CH}_{4}$ beschikbaar is voor elektraopwekking. In het algemeen wordt aangenomen dat $\mathrm{CH}_{4}$-slip uit de WKK niet te voorkomen is. Wel kan geprobeerd worden om de lekkage uit de vergister zelf (bijv. een lek in de afdekking van de silo of een lekkende verbinding) te minimaliseren; hiervoor wordt in het referentiescenario $3 \%$ aangenomen.

\subsection{Verhouding $\mathrm{CH} 4$ : $\mathrm{CO} 2$ in de stal}

In de modelberekeningen die in de voorgaande paragrafen zijn besproken, wordt aangenomen dat de emissie uit de stal kan geschat worden op basis van de opslagduur en een bepaalde MCF ( $17 \%$ bij een opslagcapaciteit van 6 maanden), uitgaand van een gegeven BMP van de verse mest. Deze MCF waarde is gebaseerd op diverse literatuurbronnen (Groenestein et al., 2016). In de literatuur wordt de MCF waarde in de regel berekend op basis van in de praktijk gemeten $\mathrm{CH}_{4}$ emissies en een in het laboratorium bepaalde BMP onder anaerobe omstandigheden. Dit impliceert dat de verhouding tussen $\mathrm{CH}_{4}$ en $\mathrm{CO}_{2}$ in de praktijk hetzelfde is als in de BMP test die in het laboratorium wordt uitgevoerd. Meestal wordt voor biogas een verhouding van ca. 60 vol\% $\mathrm{CH}_{4}$ versus 40 vol\% $\mathrm{CO}_{2}$ aangenomen, hetgeen gelijk is aan de massaverhouding op basis van $\mathrm{C}$ (dus 60 massa\% $\mathrm{CH}_{4}-\mathrm{C}$ versus 40 massa\% $\mathrm{CO}_{2}-\mathrm{C}$ ) aangezien het molaire gasvolume gelijk is. Een controle waarbij in het laboratorium nagegaan wordt of na het optreden van de emissie van $17 \%$ van de BMP, inderdaad nog $83 \%$ van de oorspronkelijke BMP resteert in de mest uit de stal, ontbreekt in het algemeen in deze onderzoeken. Daarnaast is in de literatuur vaak niet duidelijk hoe vers de mest is waarvan de BMP wordt bepaald (dat wil zeggen hoe lang deze al in de put heeft gezeten), terwijl dit wel een grote invloed kan hebben op de uitkomst van de BMP test. Bij analyse van oudere mest zal een lagere BMP worden gevonden omdat een deel van de $\mathrm{CH}_{4}$ al is vrijgekomen.

In recent onderzoek (zie bijv. Petersen et al., 2016) wordt gesuggereerd dat de verhouding $\mathrm{CH}_{4}: \mathrm{CO}_{2}$ die in de praktijk in de stal gevonden wordt wel eens lager kan zijn dan de genoemde verhouding 60 : 40 en een waarde van 85 : 15 zou kunnen hebben. Dit zou betekenen dat er meer $\mathrm{CO}_{2}$ uit de mest wordt geproduceerd dan in het laboratorium onder anaerobe omstandigheden het geval is. De consequentie daarvan zou zijn dat OS afbraak in de stal wordt onderschat wanneer deze berekend wordt op basis van de in de stal gemeten $\mathrm{CH}_{4}$-productie (MCF als fractie van BMP), zoals nu gangbaar is. 
Voor het model dat we in dit rapport hebben gebruikt voor het berekenen van de productie en emissies van $\mathrm{CH}_{4}$ heeft dit ook gevolgen.

Enerzijds is het mogelijk dat de waarde die het model berekent voor de totale afbraak van organische stof tijdens opslag in de mestkelder correct is, maar dat er sprake is van een andere volumeverhouding $\mathrm{CH}_{4}: \mathrm{CO}_{2}$. Wanneer deze niet $60: 40$ maar $85: 15$ bedraagt, zou de $\mathrm{CH}_{4}$-emissie uit de stal lager zijn maar zou de mest na 6 maanden opslag nog steeds $83 \%$ van de oorspronkelijke BMP bevatten.

Anderzijds is het denkbaar dat de $\mathrm{CH}_{4}$-emissie uit de stal bij een opslagcapaciteit van 6 maanden daadwerkelijk gelijk is aan de MCF x BMP waarde, maar dat de afbraak van de OS hoger is dan eerder werd berekend. Dit zou betekenen dat de biogasopbrengst van een nageschakelde vergister lager wordt, omdat het deel van de OS dat in de stal wordt omgezet in $\mathrm{CO}_{2}$ dan hoger is dan eerder werd aangenomen. Deze situatie wordt in Figuur 13 getoond. In vergelijking met de eerdere berekeningen wordt aangenomen dat de volumeverhouding $\mathrm{CH}_{4}: \mathrm{CO}_{2}$ van het in de stal geproduceerde biogas niet 60 : 40 maar 15 : 85 bedraagt en dat tegelijkertijd de $\mathrm{CH}_{4}$-emissie uit de stal gelijk is aan de waarde uit de eerdere berekeningen.

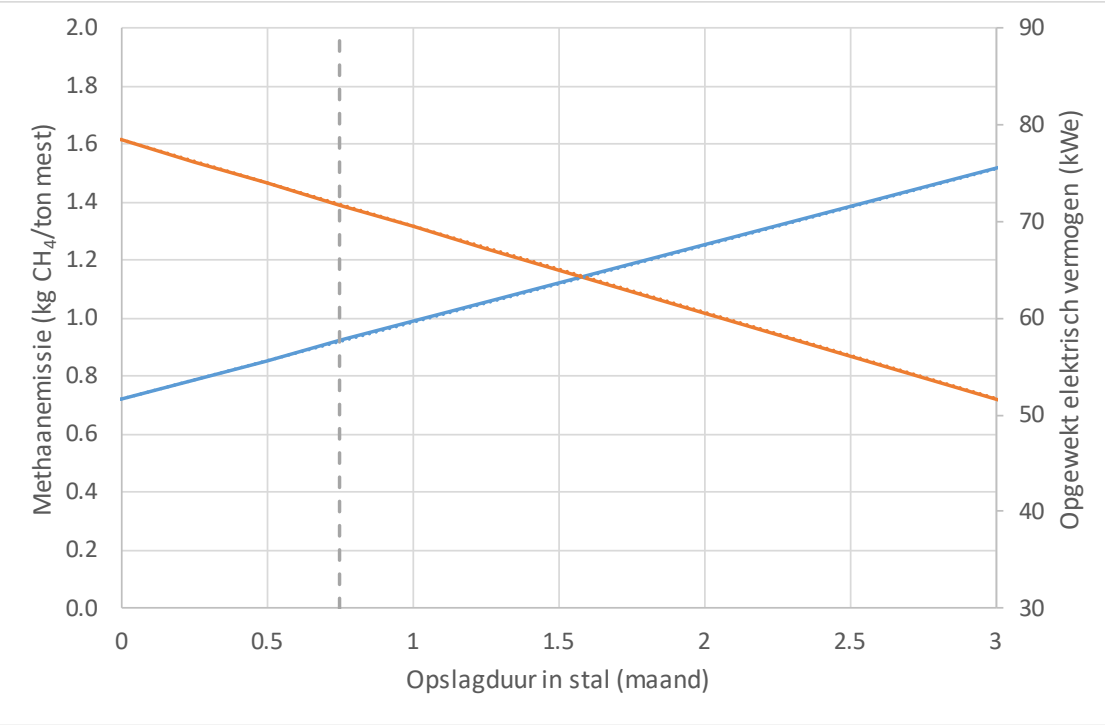

Figur 13 Invloed van duur van mestopslag in stal (voorafgaand aan vergisting) op emissie van $\mathrm{CH}_{4}$ (blauw) en opgewekt elektrisch vermogen (oranje) bij $\mathrm{CH}_{4}: \mathrm{CO}_{2}=\mathbf{1 5}$ vol\% : 85 vol\% en gelijkblijvende $\mathrm{CH}_{4}$-productie in stal. Referentie-situatie: Scenario 2 met 0,75 maanden opslag (verticale stippellijn).

Uit vergelijking van Figuur 13 en Figuur 10 blijkt dat de $\mathrm{CH}_{4}$-emissie van het scenario bij een opslagduur van 0,75 maanden in de stal afneemt van 0,98 naar 0,92 $\mathrm{kg} \mathrm{CH}_{4} /$ ton mest, een afname van $6 \%$. De reden hiervoor is dat de lekkages uit vergister en digestaatopslag afnemen als gevolg van de lagere $\mathrm{CH}_{4}$-productie in de vergister, ook al is de $\mathrm{CH}_{4}$-emissie uit de stal zelf ongewijzigd gebleven. De elektra-productie bij een opslagduur van 0,75 maanden in de stal neemt af van 77 naar $72 \mathrm{kWe}$, een afname van $7 \%$, als direct gevolg van de lagere $\mathrm{CH}_{4}$-opbrengst (de opbrengst is lager omdat een groter deel van de OS in de stal is omgezet in $\mathrm{CO}_{2}$, en dus niet meer in $\mathrm{CH}_{4}$ kan worden omgezet).

Verder blijkt dat het verband tussen opslagduur in de stal en elektra-opbrengst in Figuur 13 veel sterker is dan in Figuur 10. Dit lijkt in lijn met berichten uit de praktijk dat de $\mathrm{CH}_{4}$-opbrengst van de vergister (oftewel de biogas- en/of elektriciteitsproductie) sterk afneemt wanneer geen 'verse' mest wordt vergist maar 'oude' mest die al langere tijd in de stal opgeslagen is geweest. Figuur 13 laat zien dat bij een opslagduur van 3 maanden de biogasopbrengst en dus elektra-opbrengst, 34\% lager is dan wanneer verse mest wordt vergist (daalt van 78 naar $52 \mathrm{kWe}$ ), of zelfs $68 \%$ bij een opslagduur van 6 maanden (wanneer de lijn verder wordt doorgetrokken). 
Wanneer wel uitgegaan wordt van een volumeverhouding $\mathrm{CH}_{4}: \mathrm{CO}_{2}$ van $60: 40$ en een MCF van 17\% bij een opslagduur van 6 maanden, zou de biogasopbrengst van de vergister maar met $17 \%$ afnemen wanneer geen verse mest wordt vergist maar mest die 6 maanden in opslag is geweest (de aangenomen MCF is dan namelijk $17 \%$ ).

De berichten uit de praktijk over de sterke afname van biogasproductie bij vergisting van 'oude' mest ondersteunen dus de suggestie uit het onderzoek van Petersen et al. (2016) dat er sprake zou zijn van een lagere $\mathrm{CH}_{4}: \mathrm{CO}_{2}$ verhouding in de stal, dan de $60: 40$ verhouding waarvan nu in het algemeen wordt uitgegaan. 
Het blijkt lastig te zijn om de resultaten van buitenlandse literatuur kwantitatief te vertalen naar de Nederlandse situatie omdat factoren die van doorslaggevend belang zijn fors kunnen verschillen: de mest, en dus de organische stof daarin, zijn verschillend van kwaliteit en kwantiteit door verschillend voer- en mestmanagement. Daarnaast zijn de omgevingstemperaturen gedurende de opslag vaak anders, zeker als je daarin meeneemt dat in Nederland mest gedurende 7 maanden niet mag worden uitgereden en de silo's in de zomer minder of niet gevuld zijn. Opslag is in Nederland vaak in kelders alvorens de mest naar een externe opslag (bijv. silo) gaat. In veel landen hebben rundveestallen dichte vloeren en dus alleen mestopslag buiten, al dan niet gescheiden in een dikke en dunne fractie. In Nederland wordt zeer weinig strooisel gebruikt in reguliere stallen, in het buitenland kan dat veel meer zijn en wordt vaker stro of zand gebruikt, ook al wordt dat niet altijd vermeld in de papers.

In de literatuur wordt gevonden dat $\mathrm{CH} 4-$ verliezen uit biogasinstallaties in sommige gevallen relatief klein zijn $(<1 \%)$, maar in sommige gevallen $>5 \%$. Belangrijke BKG bronnen die in de internationale literatuur worden beschreven zijn de opslagen van mest, digestaat en/of de scheidingsproducten. Deze opslagen zijn meestal niet afgedekt en/of gasdicht gemaakt. Wanneer we het mitigerende effect van de vergister/vergisting willen kwantificeren op de hele mestmanagement-keten is het van belang te kijken naar hoe de vergisting in de keten is geïmplementeerd. Factoren die daarbij van belang zijn, zijn opslagtermijn, temperatuur en de vraag of er nog oude mest in opslag zat (inoculum) wanneer deze opnieuw gevuld wordt. De combinatie en onderlinge afhankelijkheid van deze drie factoren kan een groot verschil maken voor de uiteindelijke $\mathrm{CH} 4$-emissie. Ook moet gekeken worden naar de kwaliteit (lees: afbreekbaarheid) van de OS aangezien deze een direct effect heeft op de potentiele emissie van digestaat en verse mest. Ten slotte bleek dat het primair scheiden van de mest in de stal in combinatie met het vergisten van deze verse, dikke fractie een efficiëntieverbetering op kan leveren voor de mestvergister, wanneer dit vergeleken wordt met vergisting van ongescheiden drijfmest.

In de scenariostudie is mono-vergisting vergeleken met de situatie waarin geen vergisting wordt toegepast. Uit de berekeningen blijkt dat de absolute $\mathrm{CH}_{4}$-emissie uit mest met $61-75 \%$ afneemt voor de verschillende scenario's met mono-vergisting. Doordat het geproduceerde $\mathrm{CH} 4$ wordt aangewend voor de productie van 'groene energie', neemt de $\mathrm{CO}_{2}$-footprint van het bedrijf nog in sterkere mate af. Daarnaast is gekeken op welke wijze de $\mathrm{CH}_{4}$-verliezen kunnen beïnvloed worden door management en techniek. Hierbij is gekeken naar de volgende vier factoren: 1) mate van weidegang, 2) duur van mestopslag in de stal, 3) duur van digestaatopslag met gasopvang en 4) lekkagepercentage van de vergistingsinstallatie. Uit een gevoeligheidsanalyse blijkt dat invloed van de mate van weidegang relatief beperkt is, maar dat de andere drie factoren een grote invloed hebben op de $\mathrm{CH} 4$-verliezen en als gevolg daarvan ook op de elektriciteitsopbrengst en de totale $\mathrm{CO}_{2}$-footprint van het bedrijf. De duur van de mestopslag in de stal en omvang van de gasdichte digestaatopslag zijn keuze die gemaakt worden op het moment dat de installatie wordt gebouwd en zijn daarna niet meer gemakkelijk te wijzigen. Het optreden van lekkage uit de vergister is wel te beïnvloeden, voor zover het beschadigen en lekkages van afdekkingen, leidingen en appendages betreft. Daarmee ligt deze actie binnen het handelingsperspectief van de veehouder. Een reductie van het totale lekpercentage van $4 \%$ naar $2 \%$, zou een $\mathrm{CH} 4-$ emissiereductie van $29 \%$ tot gevolg hebben volgens de berekeningen. Aanbevolen wordt om op regelmatige basis (bijvoorbeeld eens per jaar) de installatie te controleren op $\mathrm{CH}_{4}$-emissies en eventuele lekken te repareren. Voor de controle zou een $\mathrm{CH}_{4}$-gas-detectiecamera kunnen worden gebruikt of een draagbare $\mathrm{CH}_{4}$-analyzer (TDL). Ondanks dat de internationale studies moeilijk te vergelijken zijn met de Nederlandse situatie komt wel overeen dat met betrekking tot de $\mathrm{CO}_{2}$ footprint het risico van lekkage van de vergister en de opslagen van mest en digestaat sleutelfactoren zijn. 


\section{Literatuur}

Aguirre-Villegas, H. A., R. Larson and D. J. Reinemann (2014). "From waste-to-worth: energy, emissions, and nutrient implications of manure processing pathways." Biofuels Bioproducts \& Biorefining-Biofpr 8(6): 770-793.

Angelidaki, I., M. Alves, D. Bolzonella, L. Borzacconi, J. Campos, A. Guwy, S. Kalyuzhnyi, P. Jenicek and J. Van Lier (2009). "Defining the biomethane potential (BMP) of solid organic wastes and energy crops: a proposed protocol for batch assays." Water science and technology 59(5): 927934.

Baldé, H., A. C. VanderZaag, S. Burtt, L. Evans, C. Wagner-Riddle, R. L. Desjardins and J. D. MacDonald (2016). "Measured versus modeled methane emissions from separated liquid dairy manure show large model underestimates." Agriculture, ecosystems \& environment 230: 261-270.

Baral, K. R., G. Jégo, B. Amon, R. Bol, M. H. Chantigny, J. E. Olesen and S. O. Petersen (2018). "Greenhouse gas emissions during storage of manure and digestates: Key role of methane for prediction and mitigation." Agricultural systems 166: 26-35.

Büeler, E. (2011). "CH4-Emissionen bei EPDM-Gasspeichern und deren wirtschaftlichen und ökologischen Folgen." Report for Swiss Bundesamt für Energie (BFE), Switzerland. Report 103309.

Coenen, P., C. van der Maas, P. Zijlema, E. Arets, K. Baas, A. van den Berghe, M. Nijkamp, E. van Huis, G. Geilenkirchen and C. Versluijs (2016). "Greenhouse gas emissions in the Netherlands 1990-2013: National Inventory Report 2015." RIVM Report 2015-0188.

Dämmgen, U., B. Amon, N. J. Hutchings, H.-D. Haenel and C. Roesemann (2012). "Data sets to assess methane emissions from untreated cattle and pig slurry and solid manure storage systems in the German and Austrian emission inventories." Landbauforschung Völkenrode 62(1/2): 1-19.

Daniel-Gromke, J., J. Liebetrau, V. Denysenko and C. Krebs (2015). "Digestion of bio-waste-GHG emissions and mitigation potential." Energy, sustainability and Society 5(1): 3.

Den Boer, D., J. Reijneveld, J. Schroder and J. Van Middelkoop (2012). Mestsamenstelling in adviesbasis bemesting grasland en voedergewassen, Wageningen UR Livestock Research, Commissie Bemesting Grasland en Voedergewassen. Report 1

EC (2018). "Product Environmental Footprint Category Rules Guidance (PEFCR Guidance) v6.3." European Commision.

Fangueiro, D., J. Coutinho, D. Chadwick, N. Moreira and H. Trindade (2008). "Effect of Cattle Slurry Separation on Greenhouse Gas and Ammonia Emissions during Storage." Journal of environmental quality 37(6): 2322-2331.

Flesch, T. K., R. L. Desjardins and D. Worth (2011). "Fugitive methane emissions from an agricultural biodigester." Biomass and Bioenergy 35(9): 3927-3935.

FNR (2010). "Leitfaden Biogas-Von der Gewinnung zur Nutzung." Fachagentur Nachwachsende Rohstoffe e.V Gülzow-Prüzen, Duitsland: 274.

Fredenslund, A. M. and C. Scheutz (2017). Total methane loss from biogas plants, determined by tracer dispersion measurements. Sardinia 2017, 16th International Waste Management and Landfill Symposium, CISA Publisher.

Groenestein, C., J. Mosquera and R. Melse (2016). Methaanemissie uit mest: schatters voor biochemisch methaan potentieel (BMP) en methaanconversiefactor (MCF), Wageningen Livestock Research. Rapport 916.

Groenestein, C. M. (2006). Environmental aspects of improving sow welfare with group housing and straw bedding. . Animal Sciences Group Wageningen Wageningen University \& Research. Doctor of Philosophy.

Groenestein, C. M., P. Bikker, P. Hoeksma, R. Zom and C. van Bruggen (2015). Excretieforfaits van mest: verschillen tussen berekende en gemeten N/P2O5 ratio's in mest, Wageningen UR (University \& Research centre) Livestock Research. Livestock Research Rapport 748.

Groenestein, C. M., J. Mosquera and N. W. M. Ogink (2011). Protocol voor meting van methaanemissie uit huisvestingssystemen in de veehouderij $2010=$ Measurement protocol for methane emission from housing systems in livestock production 2010. Lelystad, Wageningen UR Livestock Research. Rapport 493: 32. 
Groenestein, C. M. and B. Reitsma (1993). Potstal voor melkvee. Wageningen, Dienst Landbouwkundig Onderzoek; . Rapport: 93-1005.

Groth, A., C. Maurer, M. Reiser and M. Kranert (2015). "Determination of methane emission rates on a biogas plant using data from laser absorption spectrometry." Bioresource technology 178: 359361.

Haeussermann, A., E. Hartung, E. Gallmann and T. Jungbluth (2006). "Influence of season, ventilation strategy, and slurry removal on methane emissions from pig houses." Agriculture, ecosystems \& environment 112(2-3): 115-121.

Hjort-Gregersen, K. (2013). "Methane emission from Danish biogas plants." Economic Impact of Identified Methane Leakages. Project: ForskEl 2013-1-12093.

Hjort-Gregersen, K. (2014). "Methane emission from Danish biogas plants - Economic Impact of Identified Methane Leakages." Project: ForskEl 2013-1-12093. Agrotech, Denmark(Web: http://agrotech.dk/sites/agrotech.dk/files/public/economic_impact_of_identified_methane_leakag es.pdf).

Holmgren, M. A. (2012). "Sammanställning av mätningar inom frivilligt åtagande 2007- 2012 (Compilation of measurement results within the voluntary agreement 2007- 2012)." Avfall Sverige U2012:15, Malmö, 2012.

Holmgren, M. A., M. N. Hansen, T. Reinelt, T. Westerkamp, L. Jørgensen, C. Scheutz and A. Delre (2015). "Measurements of methane emissions from biogas production-Data collection and comparison of measurement methods." Energiforsk report 2015: 158.

Hrad, M., M. Piringer and M. Huber-Humer (2015). "Determining methane emissions from biogas plants-Operational and meteorological aspects." Bioresource technology 191: 234-243.

Hrad, M., M. Piringer and M. Huber-Humer (2017). Quantification of methane emissions from anaerobic digestion plants using laser absorption spectroscopy and inverse dispersion modelling. Proceedings Sardinia 2017. Sixteenth International Waste Management and Landfill Symposium. 2 - 6 October 2017, S. Margherita di Pula, Cagliari, Italy.

IPCC (2006). "Guidelines for national greenhouse gas inventories." Prepared by the National Greenhouse Gas Inventories Programme. Eggleston HS, Buendia L, Miwa K, Ngara T, Tanabe K, editors. Published: IGES, Japan.

Jayasundara, S., J. Ranga Niroshan Appuhamy, E. Kebreab and C. Wagner-Riddle (2016). "Methane and nitrous oxide emissions from Canadian dairy farms and mitigation options: An updated review." Canadian Journal of Animal Science 96(3): 306-331.

Lagerwerf, L., A. Bannink, C. van Bruggen, C. Groenestein, J. Huijsmans, J. van der Kolk, H. Luesink, S. van der Sluis, G. Velthof and J. Vonk (2019). Methodology for estimating emissions from agriculture in the Netherlands: Calculations of $\mathrm{CH} 4, \mathrm{NH} 3, \mathrm{N2O}, \mathrm{NOx}, \mathrm{NMVOC}, \mathrm{PM} 10, \mathrm{PM} 2.5$ and CO2 with the National Emission Model for Agriculture (NEMA), Update 2019, National Institute for Public Health and the Environment (RIVM). WOt technical report 148.

Liebetrau, J., T. Reinelt, A. Agostini and A. Wellinger (2017). Methods for measurement, results and effect on greenhouse gas balance of electricity produced. IEA Bioenergy Task.

Liebetrau, J., T. Reinelt, J. Clemens, C. Hafermann, J. Friehe and P. Weiland (2013). "Analysis of greenhouse gas emissions from 10 biogas plants within the agricultural sector." Water science and technology 67(6): 1370-1379.

Liu, Z. and Y. Liu (2018). "Mitigation of greenhouse gas emissions from animal production." Greenhouse Gases: Science and Technology 8(4): 627-638.

Maldaner, L., C. Wagner-Riddle, A. C. VanderZaag, R. Gordon and C. Duke (2018). "Methane emissions from storage of digestate at a dairy manure biogas facility." Agricultural and forest meteorology 258: 96-107.

Monteny, G. J., C. M. Groenestein and M. A. Hilhorst (2001). "Interactions and coupling between emissions of methane and nitrous oxide from animal husbandry." Nutrient cycling in Agroecosystems 60: 123-132.

Mosquera, J., C. M. Groenestein and N. W. M. Ogink (2011). Protocol voor meting van lachgasemissie uit huisvestingssystemen in de veehouderij $2010=$ Measurement protocol for nitrous oxide emission from housing systems in livestock production 2010. Lelystad, Wageningen UR Livestock Research. Rapport 494: 33.

Mosquera, J., J. Hol, A. Winkel, F. Gerrits, N. Ogink and A. Aarnink (2010). Fijnstofemissie uit stallen: melkvee $=$ Dust emission from animal houses: dairy cattle, Wageningen UR Livestock Research. Rapport 296. 
Mosquera, J., J. M. G. Hol, J. W. H. Huis in 'T Veld, J. P. M. Ploegaert and N. W. M. Ogink (2012a). Emissies uit een ligboxenstal voor melkvee met het "vrije keuze" systeem : meetprogramma Integraal Duurzame Stallen. Lelystad, Wageningen UR Livestock Research. Rapport 615: 31.

Mosquera, J., J. M. G. Hol, J. W. H. Huis in 'T Veld, J. P. M. Ploegaert and N. W. M. Ogink (2012b). Emissies uit een ligboxenstal voor melkvee met het "vrije keuze" systeem : meetprogramma Integraal Duurzame Stallen. Lelystad, Wageningen UR Livestock Research. Rapport 616: 31.

Mosquera, J., J. M. G. Hol, J. W. H. Huis in 'T Veld, J. P. M. Ploegaert and N. W. M. Ogink (2012c). Emissies uit een ligboxenstal voor melkvee met het "vrije keuze" systeem : meetprogramma Integraal Duurzame Stallen. Lelystad, Wageningen UR Livestock Research. Rapport 614: 31.

Mosquera, J., J. M. G. Hol, J. W. H. Huis in 'T Veld, J. P. M. Ploegaert and N. W. M. Ogink (2012d). Emissies uit een ligboxenstal voor melkvee met het "vrije keuze" systeem : meetprogramma Integraal Duurzame Stallen. Lelystad, Wageningen UR Livestock Research. Rapport 617: 31.

Mosquera, J., J. M. G. Hol, J. W. H. Huis in 't Veld, J. P. M. Ploegaert and N. W. M. Ogink (2012e). Emissies uit een ligboxenstal voor melkvee met roostervloer voorzien van cassettes in de roosterspleten : meetprogramma Integraal Duurzame Stallen. Lelystad, Wageningen UR Livestock Research. Rapport 653.

Mosquera, J., J. M. G. Hol, J. W. H. Huis in 'T Veld, J. P. M. Ploegaert and N. W. M. Ogink (2012f). Emissies uit een ligboxenstal voor melkvee met roostervloer voorzien van een bolle rubber toplaag : meetprogramma Integraal Duurzame Stallen. Lelystad, Wageningen UR Livestock Research. Rapport 610: 27.

Mosquera, J., J. M. G. Hol, J. W. H. Huis in 'T Veld, J. P. M. Ploegaert and N. W. M. Ogink (2012g). Emissies uit een ligboxenstal voor melkvee met roostervloer voorzien van een bolle rubber toplaag en afdichtflappen in de roosterspleten : meetprogramma Integraal Duurzame Stallen. Lelystad, Wageningen UR Livestock Research. Rapport 612: 31.

Mosquera, J., J. M. G. Hol, J. W. H. Huis in 'T Veld, J. P. M. Ploegaert and N. W. M. Ogink (2012h). Emissies uit een ligboxenstal voor melkvee met roostervloer voorzien van een bolle rubber toplaag en afdichtflappen in de roosterspleten : Meetprogramma Integraal Duurzame Stallen. Lelystad, Wageningen UR Livestock Research. Rapport 598: 27.

Pardo, R. and F. Calvo (2016). "Attitudes toward science among the European public: a methodological analysis." Public understanding of science.

Perazzolo, F., G. Mattachini, E. Riva and G. Provolo (2017). "Nutrient Losses during Winter and Summer Storage of Separated and Unseparated Digested Cattle Slurry." Journal of environmental quality 46(4): 879-888.

Petersen, S. O. (2018). "Symposium review: Greenhouse gas emissions from liquid dairy manure: Prediction and mitigation." Journal of Dairy Science 101(7): 6642-6654.

Petersen, S. O., A. B. Olsen, L. Elsgaard, J. M. Triolo and S. G. Sommer (2016). "Estimation of methane emissions from slurry pits below pig and cattle confinements." PLoS ONE 11(8).

Reijs, J. W. (2007). Improving slurry by diet adjustments: a novelty to reduce $\mathrm{N}$ losses from grassland based dairy farms. Wageningen Wageningen University. Doctor of Philosophy.

Reinelt, T., T. Clauß and J. Liebetrau (2017). "Monitoring of methane emissions from biogas plants." Gas for energy Issue 2/2017.

Reinelt, T., J. Liebetrau and M. Nelles (2016). "Analysis of operational methane emissions from pressure relief valves from biogas storages of biogas plants." Bioresource technology 217: 257264.

Rotz, C. A. and S. D. Hafner (2011). Whole farm impact of anaerobic digestion and biogas use on a New York dairy farm. 2011 Louisville, Kentucky, August 7-10, 2011, American Society of Agricultural and Biological Engineers.

Safley Jr, L. and P. Westerman (1992). "Performance of a low temperature lagoon digester." Bioresource technology 41(2): 167-175.

Sefeedpari, P., T. Vellinga, S. Rafiee, M. Sharifi, P. Shine and S. H. Pishgar-Komleh (2019). "Technical, environmental and cost-benefit assessment of manure management chain: A case study of large scale dairy farming." Journal of Cleaner Production 233: 857-868.

Torrellas, M., L. Burgos, L. Tey, J. Noguerol, V. Riau, J. Palatsi, A. Antón, X. Flotats and A. Bonmatí (2018). "Different approaches to assess the environmental performance of a cow manure biogas plant." Atmospheric environment 177: 203-213. 
van Bruggen, C. v., A. Bannink, C. Groenestein, J. Huijsmans, H. Luesink, S. Van der Sluis, G. Velthof and J. Vonk (2018). Emissies naar lucht uit de landbouw in 2017: Berekeningen met het model NEMA, Wageningen, WOT Natuur \& Milieu. WOt technical report 147.

VanderZaag, A., J. MacDonald, L. Evans, X. Verge and R. Desjardins (2013). "Towards an inventory of methane emissions from manure management that is responsive to changes on Canadian farms." Environmental Research Letters 8(3): 035008.

VanderZaag, A. C., H. Baldé, A. Crolla, R. J. Gordon, N. M. Ngwabie, C. Wagner-Riddle, R. Desjardins and J. D. MacDonald (2018). "Potential methane emission reductions for two manure treatment technologies." Environmental technology 39(7): 851-858.

Vonk, J., S. van der Sluis, A. Bannink, C. van Bruggen, C. Groenestein, J. Huijsmans, J. van der Kolk, L. Lagerwerf, H. Luesink and S. Oude Voshaar (2018). Methodology for estimating emissions from agriculture in the Netherlands-update 2018: calculations of $\mathrm{CH} 4, \mathrm{NH} 3, \mathrm{~N} 2 \mathrm{O}, \mathrm{NOx}, \mathrm{PM} 10, \mathrm{PM} 2.5$ and $\mathrm{CO} 2$ with the National Emission Model for Agriculture (NEMA), National Institute for Public Health and the Environment (RIVM). WOt-technical report 115.

Vu, P. T., R. W. Melse, G. Zeeman and P. W. G. Koerkamp (2016). "Composition and biogas yield of a novel source segregation system for pig excreta." biosystems engineering 145: 29-38.

Westerkamp, T., T. Reinelt, K. Oehmichen, J. Ponitka and K. Naumann (2014). "KlimaCH4. Climate effects of biomethane economy." KlimaCH4. Klimaeffekte von Biomethan DBFZ--20.

Zom, R. L. G. and C. M. Groenestein (2015). Excretion of volatile solids by livestock to calculate methane production from manure. . TC-O 20 Advances in emission prevention, RAMIRAN 2015 16th International Conference Rural-Urban Symbiosis. 8th - 10th September 2015, Hamburg, Germany. 


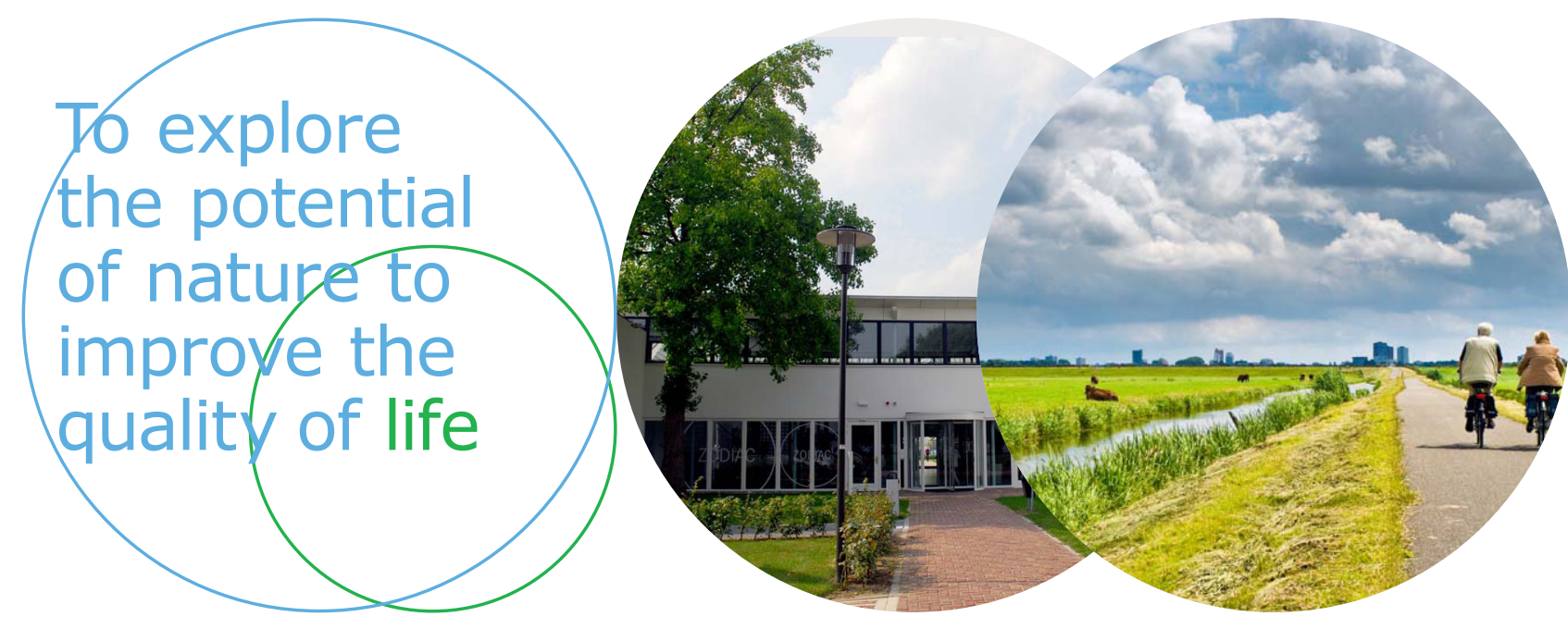

Wageningen Livestock Research Postbus 338

$6700 \mathrm{AH}$ Wageningen

T 0317483953

E info.livestockresearch@wur.nl www.wur.nl/livestock-research
Wageningen Livestock Research ontwikkelt kennis voor een zorgvuldige en renderende veehouderij, vertaalt deze naar praktijkgerichte oplossingen en innovaties, en zorgt voor doorstroming van deze kennis. Onze wetenschappelijke kennis op het gebied van veehouderijsystemen en van voeding, genetica, welzijn en milieu-impact van landbouwhuisdieren integreren we, samen met onze klanten, tot veehouderijconcepten voor de $21 \mathrm{e}$ eeuw.

De missie van Wageningen University \& Research is 'To explore the potential of nature to improve the quality of life'. Binnen Wageningen University \& Research bundelen 9 gespecialiseerde onderzoeksinstituten van Stichting Wageningen Research en Wageningen University hun krachten om bij te dragen aan de oplossing van belangrijke vragen in het domein van gezonde voeding en leefomgeving. Met ongeveer 30 vestigingen, 6.500 medewerkers en 10.000 studenten behoort Wageningen University \& Research wereldwijd tot de aansprekende kennisinstellingen binnen haar domein. De integrale benadering van de vraagstukken en de samenwerking tussen verschillende disciplines vormen het hart van de unieke Wageningen aanpak. 